Discussion Paper No. 09-061

Searching for Innovation in Market and Transition Economies:

Evidence Across Europe

Wolfgang Sofka and Christoph Grimpe

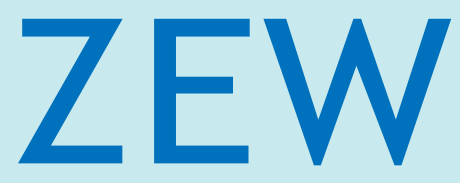

Zentrum für Europäische Wirtschaftsforschung $\mathrm{GmbH}$

Centre for European

Economic Research 
Discussion Paper No. 09-061

\title{
Searching for Innovation in Market and Transition Economies: Evidence Across Europe
}

\author{
Wolfgang Sofka and Christoph Grimpe
}

Download this ZEW Discussion Paper from our ftp server:

ftp://ftp.zew.de/pub/zew-docs/dp/dp09061.pdf

Die Discussion Papers dienen einer möglichst schnellen Verbreitung von neueren Forschungsarbeiten des ZEW. Die Beiträge liegen in alleiniger Verantwortung der Autoren und stellen nicht notwendigerweise die Meinung des ZEW dar.

Discussion Papers are intended to make results of ZEW research promptly available to other economists in order to encourage discussion and suggestions for revisions. The authors are solely responsible for the contents which do not necessarily represent the opinion of the ZEW. 


\section{Non-technical summary}

The extant innovation literature has recognized for a long time that a firm's innovation performance does not only depend on internal research and development (R\&D) activities but instead on a skilled bundling of internal and external knowledge resources. In fact, many firms have opened up their innovation processes and deliberately searched for external knowledge from sources such as customers, suppliers, competitors or universities. The search strategy, providing firms with a mechanism to learn and their organizational knowledge bases to evolve, has been found to substantially impact innovation performance. Although this organization-focused approach has successfully opened the black box of how firms deploy knowledge resources to innovate, it risks neglecting relevant characteristics of the environment in which a firm operates. On the contrary, the institutional approach, advocated by researchers analyzing national systems of innovation, suggests that each country has unique characteristics in terms of organizations and institutional infrastructures for innovation which determine innovativeness. Such infrastructure could for example be universities and research institutes generating and diffusing new technological knowledge or, in a broader view, industrial relations, legal frameworks, or a society's customs and culture. The institutional approach thus stresses the contingencies affecting innovation performance of firms but overlooks differences in firms' knowledge and innovation capabilities.

While the organizational knowledge base of an innovating firm is certainly important, recent contributions have acknowledged that firm strategies are influenced by the particular institutional context. Institutional differences are probably nowhere more pronounced than between developed market economies and former command economies which have been in transition since the fall of the "iron curtain" in 1989 and the collapse of the Soviet Union in 1991. In this paper, we consider the interaction between organizations and institutions. The objective is to shed new light on the importance of the institutional context of developed Western European market economies and transition economies from Central and Eastern Europe (CEE) for a firm's search and innovation behavior.

The empirical part of this research is based on the third Community Innovation Survey (CIS-3), providing insights into the innovation processes of firms from ten European countries using a latent class methodology. The data provide the unique opportunity to compare search strategies from the developed market economies Belgium, Germany, Spain, Greece and Portugal with the transition economies Lithuania, Estonia, Hungary as well as the Czech and Slovak Republics. Our results show that search strategies differ considerably between established market and transition economies. Moreover, search in transition economies is characterized by much more variety. However, in these countries management capacity is a particularly scarce resource which is why focused search strategies turn out to be most successful. We derive targeted management and policy recommendations as we obtain finegrained input-output relationships for different institutional infrastructures and different search patterns. 


\section{Das Wichtigste in Kürze}

In der Innovationsliteratur wird seit längerem darauf hingewiesen, dass der Innovationserfolg eines Unternehmens nicht allein von internen Forschungs- und Entwicklungsaktivitäten (FuE) abhängt, sondern auch durch die geschickte Verknüpfung von internen und externen Wissensquellen entsteht. Tatsächlich haben viele Firmen ihre Innovationsprozesse geöffnet und suchen gezielt nach externem Wissen von Kunden, Zulieferern, Wettbewerbern oder Universitäten. Die Suchstrategie als Mechanismus, mit dem Firmen lernen und ihre Wissensbasis erweitern, wird dabei als wesentliche Determinante des Innovationserfolgs genannt. Obwohl dieser firmenbezogene Ansatz viele Aufschlüsse darüber gibt, wie Firmen Wissensquellen zur Innovation nutzen, besteht darin auch das Risiko, wesentliche Charakteristiken aus dem Firmenumfeld zu vernachlässigen. Im Gegensatz dazu weist der institutionelle Ansatz, der sich mit nationalen Innovationssystemen befasst, darauf hin, dass sich jedes Land durch einzigartige Charakteristiken in Bezug auf Organisationen und institutionelle Infrastrukturen, die die Innovationsfähigkeit maßgeblich beeinflussen, auszeichnet. Solche Infrastrukturen könnten beispielsweise Universitäten oder Forschungsinstitute, die technologisches Wissen generieren und verbreiten, oder im weiteren Sinne auch industrielle Beziehungen, das rechtliche Umfeld oder Gebräuche und Kultur einer Gesellschaft sein. Der institutionelle Ansatz unterstreicht somit die Umstände, die den Innovationserfolg eines Unternehmens beeinflussen, übersieht aber die unterschiedlichen Wissensstände und Ressourcenausstattungen von Unternehmen.

Während die eigene Wissensbasis eines innovativen Unternehmens zweifelsfrei von Bedeutung ist, zeigen aktuelle Beiträge, dass Unternehmensstrategien auch vom besonderen institutionellen Umfeld abhängen. Institutionelle Unterschiede sind wohl kaum deutlicher als zwischen Marktwirtschaften und ehemaligen Planwirtschaften, die seit dem Fall des „eisernen Vorhangs“ 1989 und dem Zusammenbruch der Sowjetunion 1991 im Umbruch sind. In diesem Beitrag wird das Zusammenspiel von Organisationen und Institutionen betrachtet mit dem Ziel, neue Erkenntnisse über die Bedeutung des institutionellen Umfelds von entwickelten westeuropäischen Marktwirtschaften und Volkswirtschaften in Schwellenländern in Zentral- und Osteuropa (CEE) für die Suchstrategien und das Innovationsverhalten von Unternehmen zu gewinnen.

Der empirische Teil dieser Studie basiert auf der dritten „Community Innovation Survey“ (CIS-3), in der Innovationsprozesse von Unternehmen in zehn europäischen Ländern mithilfe der Latent Class Methode untersucht werden. Unsere Ergebnisse zeigen, dass sich die Suchstrategien in entwickelten Marktwirtschaften und Schwellenländern erheblich voneinander unterscheiden. Außerdem zeichnet sich die Suche in Schwellenländern durch eine viel größere Vielfalt aus. Allerdings stellen Managementkapazitäten in diesen Ländern eine äußerst knappe Ressource dar, weshalb fokussierte Suchstrategien den größten Erfolg erzielen. Unser Beitrag schließt mit Empfehlungen für das Management von Unternehmen und die Politik. 


\title{
Searching for Innovation in Market and Transition Economies: Evidence Across Europe
}

\author{
Christoph Grimpe ${ }^{\mathrm{a}, \mathrm{b}}$ and Wolfgang Sofka ${ }^{\mathrm{c}}$ \\ ${ }^{a}$ ZEW Centre for European Economic Research, Mannheim, Germany \\ ${ }^{\mathrm{b}}$ University of Zurich, Switzerland \\ ${ }^{\mathrm{c}}$ Department of Organisation and Strategy, CentER, CIR, Tilburg University, Tilburg, \\ the Netherlands
}

\begin{abstract}
Searching for externally available knowledge has been characterized as a vital part of the innovation process. The availability of such innovation impulses, however, critically depends on the environment a firm is operating in. Little is known on how institutional infrastructures for innovation differ with respect to the munificence in providing innovation impulses. In this paper, we suggest that these differences are particularly pronounced between established market economies and transition economies. We argue that these differences shape a firm's search pattern and that the search pattern subsequently moderates the relationship between innovation inputs and outputs. Based on a sample of more than 4,500 firms from ten European countries we find that search strategies differ considerably between established market and transition economies. Search in transition economies is characterized by much more variety. However, management capacity in these countries is a particularly scarce resource which is why focused search strategies turn out to be most successful.
\end{abstract}

Keywords: Search strategies, open innovation, transition economies, institutional infrastructure for innovation

JEL-Classification: L60, O32

Corresponding author:

Christoph Grimpe

ZEW Centre for European Economic Research

Department of Industrial Economics and International Management

P.O. Box 1034 43, D-68034 Mannheim, Germany

E-mail: grimpe@zew.de

Phone: +49/621/1235-381, Fax: +49/621/1235-170

This paper has greatly benefited from discussions with Thomas P. Murtha, Christian Rammer and Jaeyong Song. Moreover, we thank Laszlo Tihanyi for organizing the Fifth Annual JIBS/AIB Paper Development Workshop in Milan, 2008. This paper has been produced as part of the Systematic Innovation Watch project within the Europe Innova Initiative, sponsored by the European Commission. Financial support is gratefully acknowledged. 


\section{Introduction}

The extant innovation literature has recognized for a long time that a firm's innovation performance does not only depend on internal research and development (R\&D) activities but instead on a skilled bundling of internal and external knowledge resources (e.g., Rosenkopf and Nerkar, 2001; Katila, 2002; Cassiman and Veugelers, 2006). In fact, many firms have opened up their innovation processes and deliberately searched for external knowledge from sources such as customers, suppliers, competitors or universities (Chesbrough, 2003). The search strategy, providing firms with a mechanism to learn and their organizational knowledge bases to evolve, has been found to substantially impact innovation performance (Katila and Ahuja, 2002; Laursen and Salter, 2006; Grimpe and Sofka, 2009). Although this organization-focused approach has successfully opened the black box of how firms deploy knowledge resources to innovate, it risks neglecting relevant characteristics of the environment in which a firm operates (Chang et al., 2006). On the contrary, the institutional approach, advocated by researchers analyzing national systems of innovation, suggests that each country has unique characteristics in terms of organizations and institutional infrastructures for innovation which determine innovativeness (Chang et al., 2006). Such infrastructure could for example be universities and research institutes generating and diffusing new technological knowledge (Nelson and Rosenberg, 1993) or, in a broader view, industrial relations, legal frameworks, or a society's customs and culture (Lundvall, 1992; Edquist, 1997). The institutional approach thus stresses the contingencies affecting innovation performance of firms but overlooks differences in firms' knowledge and innovation capabilities (Chang et al., 2006).

While the organizational knowledge base of an innovating firm is certainly important, recent contributions have acknowledged that firm strategies are influenced by the particular institutional context (Murtha and Lenway, 1994; Hoskisson et al., 2000; Meyer and Peng, 2005; Meyer et al., 2009). As a result, the institutional context is seen to be much more than "background conditions" but instead a key determinant of the strategy a firm may devise and implement to achieve competitive advantage (Meyer et al., 2009). Existing literature on the effects of a firm's search for external innovation impulses, however, largely ignores the moderating effects of the institutional context. Institutional differences are probably nowhere more pronounced than between developed market economies and former command economies which have been in transition since the fall of the "iron curtain" in 1989 and the collapse of the Soviet Union in 1991. In this paper, we consider the interaction between organizations and institutions. The objective is to shed new light on the importance of the institutional context of developed Western European market economies and transition economies from Central and Eastern Europe (CEE) for a firm's search and innovation behavior. By paying close attention to the interaction between organizations and institutions we hope to achieve a better understanding of the complex and multilevel processes underlying innovation. 
We follow Mahmood and Mitchell (2004) and Chang et al. (2006) and use the term institutional infrastructure for innovation to capture the set of systems that provides knowledge resources and facilitates the search for innovation impulses. We suggest that transitions in institutional infrastructure like those apparent in CEE countries shape unique search strategies in the sense that existing knowledge pools may run dry while new strategic opportunities emerge (Peng, 2003). In that sense, we argue that distinctive search patterns can be identified that reflect a firm's institutional context. We propose that these search patterns vary between developed market and transition economies. In addition, we assume that there is not one uniform association with innovation success but rather that the search patterns moderate the relationship between innovation input and output. In this respect, our research can be characterized as inductive in that we do not make any ex-ante assumptions about what search pattern to expect in a particular institutional context and how the pattern will influence innovation performance.

In conclusion, our research aims at extending existing literature in two ways. First, we consider the interaction between organizations and institutions and investigate whether different patterns of search strategies exist in developed and transition economies. Second, we analyze the link between these search patterns and the payoffs from R\&D investments with regard to market success. The empirical part of this research is based on the third Community Innovation Survey (CIS-3), providing insights into the innovation processes of firms from ten European countries using a latent class methodology. The data provide the unique opportunity to compare search strategies from the developed market economies Belgium, Germany, Spain, Greece and Portugal with the transition economies Lithuania, Estonia, Hungary as well as the Czech and Slovak Republics. We derive targeted management and policy recommendations as we obtain fine-grained input-output relationships for different institutional infrastructures and different search patterns.

Our paper is organized in six sections. Section 2 provides our analytical framework and develops hypotheses. Section 3 focuses on our empirical study, outlining data, variable measurement and estimation methodology. Section 4 follows, showing the results of the analysis. Based on the results, we discuss our findings in section 5. Section 6 closes with concluding remarks and implications for further research.

\section{Theoretical framework}

\subsection{Institutional infrastructures for innovation}

We choose institutional theory as our starting point and connect it to a resource-based argument by following a theoretical trajectory suggested by Hoskisson et al. (2000) who argue that institutional change in transition economies requires firms to shift towards resource creating activities to survive in competition. More precisely, we ask how the changing institutional infrastructures for innovation in transition economies affect a firm's opportunities 
for acquiring valuable knowledge from its environment, and how this knowledge acquisition differs from firms in established market economies.

Institutions in an economy define the "rules of the game" encompassing formal systems such as regulations and laws, as well as informal systems such as norms of behavior or conventions, as well as sanctioning mechanisms, which organize interactions to decrease uncertainty in exchange and offer incentives (North, 1990). Institutions constrain the choice set of actors to influence their behavior in a way that is beneficial to the common good (Ingram and Clay, 2000). These institutional rules can also provide firms with increased access to resources, for example through enforceable property rights or lower transaction costs (Jackson and Deeg, 2008).

From a comparative institutional perspective, countries vary along several dimensions (Murtha and Lenway, 1994). First of all, countries differ with respect to which economic activities are assigned to private and state ownership. Moreover, the size of these sectors is important. Second, countries rely differently on markets versus state planning to coordinate transactions among organizations and to allocate resources. In command economies, the ownership rights in productive assets are assigned to the state which centrally plans and governs the transactions of organizations. When command economies begin a transition process, the state still dominates the allocation of property rights while prices have become a coordination instrument for transactions. In contrast to command and transition economies, developed market economies typically assign all property rights to the private sector. Depending on the degree to which market economies employ corporatist elements, either unregulated markets coordinate transactions or industry associations and labor unions work in partnership with the government to influence the governance of interactions (Murtha and Lenway, 1994).

Although the transition process from a command to a market economy leads to higher institutional compatibility with the international economy, transition economies continue to exhibit shortcomings. Murtha and Lenway (1994) define a transitional economy as one where market transactions are based on prices but the allocation of property rights is heavily influenced by the state. Particularly the unclear conditions under which firms may appropriate the returns from innovation seem to be a critical factor (Teece, 1986). However, multinational firms coming into transition economies may at least in the short run be able to substitute for underdeveloped institutional infrastructure (Kogut, 1991; Murtha and Lenway, 1994). In this context, entry strategies of multinationals firms for host countries in transition (or emerging) have received considerable attention in the literature (e.g., Peng, 2003; Wright et al., 2005; Meyer et al., 2009).

Institutions also affect innovation, a perspective advocated by scholars of national innovation systems, who argue that each country is unique in terms of institutional infrastructures to support innovation (e.g., Lundvall, 1992; Nelson and Rosenberg, 1993; Edquist, 1997). In fact, developed economies with market-based transactions should be better suited to provide firms with access to innovation infrastructure. Firms may raise capital, hire skilled personnel or gain knowledge of customer demands when there are rather efficient markets for capital and labor, technologically advanced suppliers and other providers of 
business services, when property rights guarantee appropriability, or when the government is relatively free from corruption (Mahmood and Mitchell, 2004). Transition economies, by contrast, typically lack such elaborated system, making the institutional infrastructure for innovation rather weak.

Only a few studies, however, address the question how institutional infrastructures might moderate the innovativeness resulting from particular firm strategies or they focus predominantly on the role of subsidiaries of multinational enterprises. Hall and Soskice (2001) suggest that certain institutional characteristics, like the use of market versus nonmarket mechanisms to coordinate firm activity, serve as conduits to different types of innovation. Mahmood and Mitchell (2004) analyze the role of multinational business group affiliation in emerging economies for innovation. They find that group affiliation substitutes for a lack of institutional infrastructure in that affiliate firms are provided with technological knowledge, human talent, financial resources, and complementary products or services which enable them to innovate better than independent firms. Chang et al. (2006) build on this perspective and note that groups are heterogeneous to the extent they are diversified. They find that higher diversification might impede innovation performance of the group affiliate in case institutional infrastructures for innovation are well established.

While most industries have become increasingly globally integrated in recent years, research has shown that knowledge tends to be more readily diffused through regional or national innovation systems than global ones (Spencer et al., 2005). Hence, we can assume that differences between developed and transition economies persist and diminish only gradually at a slow pace. As a consequence, the possibility that an ideal firm strategy may vary across institutional infrastructures has important implications for the nature of a firm's search behavior which in turn influences the effectiveness of inputs into the innovation process being transformed into innovation outputs. An important element in a firm's innovation input is the organizational knowledge base.

\subsection{Search strategies for external knowledge}

The organizational knowledge base has frequently been characterized as the most valuable resource of the firm (Grant, 1996; Liebeskind, 1996). Traditionally, the generation of new knowledge has been ascribed to a firm's in-house R\&D activities. However, building a competitive strategy around knowledge is demanding since it could "spill over" to competitors who may, as a result, free-ride on a firm's investments into R\&D (Arrow, 1962; Jaffe, 1986). While keeping knowledge proprietary has been a consistent strategic option in the past (Liebeskind, 1997), firms shift to an increasing extent towards a model of "open innovation" (Chesbrough, 2003). They exploit the complementary character of internally generated and externally acquired knowledge (Cassiman and Veugelers, 2006). Driving factors of this development have been the increasing availability of external knowledge, for example from universities, customers and specialized suppliers (von Hippel, 1988; Link and Scott, 2005; Perkmann and Walsh, 2007; van Echtelt et al., 2008), as well as increasing competitive dynamics forcing firms to actively search for innovation impulses and move beyond traditional fields of activity (Calantone et al., 1997; Ojah and Monplaisir, 2003). In 
fact, existing research shows that using external knowledge in innovation activities pays off (e.g., Rosenkopf and Nerkar, 2001; Katila and Ahuja, 2002; Cassiman and Veugelers, 2006; Laursen and Salter, 2006).

External knowledge, however, needs to be identified, integrated and deployed to increase innovation performance (Todorova and Durisin, 2007). In other words, firms need to develop absorptive capacities which enable firms to exploit a richer set of knowledge, to solve problems, and to react to new market and technology trends (Cohen and Levinthal, 1989, 1990). Absorptive capacities have been subject to a lively discussion in the literature regarding their origins and consequences (see Lane et al., 2006, for an overview). Cohen and Levinthal (1989) have argued that absorptive capacities are basically a by-product of in-house R\&D activities as they lead to the creation of organizational routines, allowing firms to refocus the organizational knowledge base through iterative learning processes (Szulanski, 1996; Zahra and George, 2002). Absorptive capacities thus facilitate exploratory innovation through a skilled bundling of resources (Jansen et al., 2006; Subramaniam and Youndt, 2005), even though their effect differs across sources (Lane and Lubatkin, 1998) and depends on the stability of the knowledge environment (van den Bosch et al., 1999)

While literature generally aggress on the value of absorptive capacities and scanning abilities during times of institutional transition (May et al., 2000; Newman, 2000), relatively little is known about where firms would look for external knowledge. A search strategy is required to provide direction and priority for external knowledge acquisition. In this context, Katila and Ahuja (2002: 1184) define a search strategy as an “organization's problem-solving activities that involve the creation and recombination of technological ideas" which could originate from various sources in the innovation system. Laursen and Salter (2006) focus on the concepts of breadth and depth in a firm's search activities. On the one hand, more variety in terms of external sources may reduce the risk of blind spots and unexpected developments. On the other hand, Ocasio (1997) has argued that overall management attention is limited and similarly is the capacity to absorb external knowledge. Firms should therefore concentrate on a few valuable sources and exploit these in-depth (Koput, 1997). In fact, using data on the UK manufacturing sector, Laursen and Salter (2006) find an inversely U-shaped relationship between search breadth and depth and innovation performance, suggesting that firms might "over-search" their environment which requires excessive management attention (Ocasio, 1997) and actually decreases innovation performance.

Similarly, Katila and Ahuja (2002) look into the effects of search depth and search scope of firms from the robotics industry. In contrast to Laursen and Salter (2006), their definition of search depth refers to the extent to which existing knowledge is reused, while search scope denotes how broadly external knowledge is explored. In this respect, search scope largely corresponds with search breadth as in Laursen and Salter (2006) while search depth focuses on the existing organizational knowledge base within the firm. Katila and Ahuja (2002) also observe an inversely u-shaped effect of search on innovation performance, confirming the negative consequences from excessive search. In addition, they show that the interaction of firm-specific knowledge and its extension towards new applications (scope) leads to unique combinations and, as a result, to higher innovation performance. 
Laursen and Salter (2006) and Katila and Ahuja (2002), however, treat all combinations of potential external sources equally and hence ignore that certain sources might fit well together while others might not. In other words, defining search strategies along their breadth and depth underestimates the degree of heterogeneity among the various knowledge sources they encompass. In this respect, Grimpe and Sofka (2009) point to potential complementarities between specific external knowledge, for example between market-related impulses from customers and competitors or technology-related knowledge from universities, research institutes, or suppliers. They find characteristic search patterns as a combination of external knowledge sources fitting together. Moreover, they show that the adoption of search patterns is industry-specific with considerable differences between and performance implications for high-, medium- and low-technology firms.

We follow Grimpe and Sofka (2009) and look specifically into combinations of different external innovation sources which firms choose to adopt and which should vary between developed market economies and transition economies. At the heart of this assumption is the premise that market and transition economies, by offering different opportunities to acquire external knowledge, enable firms to follow search strategies in distinctive ways. The nature of this interaction, however, needs to be further delineated which is the focus of the following section.

\subsection{Potentials from external knowledge sources under different institutional infrastructures}

After the fall of the Berlin Wall and the collapse of the Soviet empire, post-socialist economies in CEE countries have struggled mainly with problems of macroeconomic adjustment and privatization, going through a painful transition from a closed command economy to a free market economy. In this respect, an almost implicit assumption had been that industrial restructuring as well as technological change would almost immediately occur once the market mechanism is in place (Radosevic, 1998). Existing formal institutions were torn down while new institutions have only emerged gradually. This has led, however, in most countries to fragmented, ambiguous and even contradictory regulations while informal institutions still persist from the socialist past. Although formal institutions transited towards a market economy, the norms of business continued to be aligned with socialism. In addition, managers had to learn how to best cope with the market and beginning international competition (Meyer and Gelbuda, 2006). This inertia, both in terms of informal institutions and people's behavior, has been characterized as a major stumbling block for business transactions, resulting in inconsistent institutions, high uncertainty and economic decline (Gelbuda et al., 2008).

Apart from the dramatic decline in almost all macro-economic performance indicators, the conversion has also heavily impeded the countries' innovation capacities, leading to an increased East-West technological divide during the 1990s (Krammer, 2009). In fact, decreasing spending and employment in $R \& D$ has led to significant differences between the East and the West in producing new knowledge, for example in terms of patents (Radosevic and Auriol, 1999). The isolation of CEE countries in socialist times from the world's flow of 
ideas resulted in substantial difficulties to catch up with the latest technologies in recent years. In other words, the lack of absorptive capacity causes even the most successful CEE countries to be currently far away from the technological frontier (Krammer, 2009). Moreover, the perspective of national systems of innovation stresses the notion that former socialist and capitalist innovation systems are rather far from each other in terms of underlying assumptions, guiding principles and instruments (Lundvall, 1992).

Economic activity in a command-style institutional environment was largely based on a complex plan of what and how firms produced. The dominant feature of this central planning was "specificity" in firm relations (Blanchard and Kremer, 1997). Within this framework firms were obliged to acquire inputs from specific suppliers and sell to specific customers. Compliance with the plan was enforced by a central planning authority. Hence, firm managers had no incentive to deviate from established routines through innovative products, processes or services. Changes in the production plan were largely the responsibility of the central planning authority, and the lack of private ownership stabilized this configuration (Meyer and Peng, 2005). Therefore, individual firm managers did typically not actively search for alternative procurement options, novel material suppliers, new customer segments or academic research ready for commercialization. Makhija and Stewart (2002) compare risk perceptions of managers from the United States and the Czech Republic. They find that under circumstances which are typical for innovation activities, such as uncertainty and incomplete information, managers from transition economies had a lower propensity to accept risks. This provides a major challenge for firms during institutional transition periods from planned to market economies. They loose the specificity of their production and knowledge environment and encounter a stage of "disorganization” (Blanchard and Kremer, 1997). Especially the transition economies in Eastern Europe experienced dramatic institutional change during the 1990s. Svejnar (2002) refers to the rapid transition as "big bang” style with market oriented reforms along several dimensions: price liberalization, private banks, monetary policy, exchange rates, reduction of subsidies to state-owned companies, etc. Given these substantial disruptions research has found that firms in transition economies performed best in these high velocity environments based on strategic flexibility and the ability of its management to establish and exploit their personal networks (Danis et al., 2009; Newman, 2000). To implement strategic flexibility management requires the relevant knowledge about its environment and its changes. May et al. (2000) identify these "scanning" capabilities of firms as especially important in sectors heavily influenced by transitions in Russia. Similarly, Newman (2000) points to a firm's level of absorptive capacity which makes it more likely to deal with institutional change.

As a consequence, while search and scanning activities in transition economies can be assumed to be highly important, product and factor markets are often underdeveloped (Wright et al., 2005). When it comes to the availability of external knowledge that firms can search for, significant differences between market and transition economies are apparent. First, contrary to established market economies, transition economies lack an established network of supporting and interrelated firms like suppliers and distributors, facilitating a firm's innovativeness by providing them with access to qualified personnel and production inputs (Chang et al., 2006). Knowledge on the improvement of technologies or potential extensions 
of innovations usually resides with the suppliers of technology components which is why a firm may benefit significantly from establishing ties with suppliers (Nelson and Rosenberg, 1993). Second, universities in CEE countries did not have an equivalent role in generating new basic knowledge as their counterparts in Western Europe. Instead, this part was assumed by the Academies of Science (AoS). Universities were more important for applied R\&D although this was dominated by industrial institutes (Radosevic, 1998). These institutes were responsible for almost all development work and an independent part of the large state-owned production facilities, so-called combinates. As a consequence, firm R\&D played only a marginal role which is in stark contrast to the situation in a market economy where in-house $\mathrm{R} \& \mathrm{D}$ dominates and universities have become important partners in technology transfer (Hall et al., 2003). This means that the privatized firms as a result from splitting up the former combinates had developed only marginal absorptive capacities. A technology transfer from universities and the AoS therefore remains often ineffective for improving innovation performance (Guan et al., 2009).

We derive two major conclusions from this discussion. First, we expect the heightened environmental dynamics from institutional change in transition economies to propel a larger variety in the choices firms make on their search strategies. Secondly, the availability of management capabilities for absorbing this external knowledge is limited in transition economies. This constrains the ability of firms in transition economies to identify, evaluate and assimilate external knowledge from a multitude of sources. As a result, firms with focused search strategies, i.e. targeting only few knowledge sources, can be expected to show superior performance with regard to the relationship between innovation inputs and outputs.

In the following, we will conduct an inductive empirical analysis on these relationships in both established market and transition economies. The identification of patters of search strategies, i.e. search patterns, is essentially an exploratory step of the analysis. We are particularly interested in the number as well as the characteristics of the search patterns that can be identified in each institutional setting respectively. These search patterns, for which we do not have any ex-ante expectations, will serve as the basis for evaluating the relationship between innovation inputs and outputs of firms within the two institutional infrastructures for innovation. In other words, the search patterns identified will moderate this relationship.

\section{$3 \quad$ Empirical study}

\subsection{Data}

For the empirical part of this analysis we use cross-sectional data from the third Community Innovation Survey (CIS-3), a survey conducted under the coordination of Eurostat, the statistical office of the European Union (EU), in 2001 on the innovation activities of enterprises in the EU member states (including all ascending and some neighboring states) with at least ten employees. For the 2001 survey, data were collected on the innovation 
activities of enterprises during the three-year period from 1998 to 2000. CIS data represent an important source of information since they offer representative firm data for all EU member states and participating neighboring countries. They cover a very relevant period for the CEE transition economies as major elements of transitory, institutional reforms were already enacted almost a decade after the fall of the Berlin wall but the CEE countries had not yet joined the EU. The Czech Republic, Estonia, Hungary, Latvia, Lithuania, Poland, Slovakia and Slovenia joined the EU in 2004, Romania and Bulgaria followed in 2007.

CIS surveys provide a wealth of information that is particularly relevant to the research questions covered here. CIS-3 data have only recently been released by Eurostat. It is important to note that these micro data have been released in the form of anonymized data. The CIS-3 anonymization method developed by Eurostat is based on a micro-aggregation process which modifies the firm level data in such a way that individual firms can no longer be identified, i.e. it is not possible to match a firm with its exact responses (Eurostat, 2005).

Although CIS-3 was performed in each EU member and some candidate states, country data availability is restricted. Our CIS-3 micro-aggregated dataset is only available for ten of the 27 EU countries. Subsidiaries of foreign firms are excluded as well as observations with missing values. We obtain almost 1,600 firm observations from five transition economies in Eastern Europe and more than 2,900 observations from five Western European established market economies. Table 1 provides a detailed overview on the composition of the sample.

Table 1: Number of observations

\begin{tabular}{lrlr}
\hline \multicolumn{1}{c}{ Transition economies } & & \multicolumn{1}{c}{ Developed market economies } \\
\hline Czech Republic & 822 & Belgium & 240 \\
Estonia & 153 & Germany & 818 \\
Hungary & 126 & Spain & 1,275 \\
Lithuania & 430 & Greece & 270 \\
Slovak Republic & 63 & Portugal & 322 \\
\hline Total & 1,594 & & 2,925 \\
\hline
\end{tabular}

CIS surveys target decision makers on firm's innovation activities. Typical respondents are CEOs as well as heads of R\&D departments or innovation management. They provide direct assessments of the usage and impact of innovation inputs, processes and outputs (Criscuolo et al., 2005). This includes a comprehensive set of external knowledge sources which is of central importance to our study. While this information is self-reported it may help to alleviate some of the shortcomings of more traditional measures in innovation research such as patent statistics. Hence, it is not surprising that several important studies in the fields of strategy and innovation management have been published recently based on CIS survey data (e.g., Laursen and Salter, 2006; Cassiman and Veugelers, 2006).

Respondents to CIS surveys are asked to provide subjective, typically qualitative assessments. Hence, requirements for survey design and implementation are high for securing response accuracy, reliable administration as well as avoiding non-response biases (for a recent discussion see Criscuolo et al., 2005). CIS surveys combine a number of quality management layers to address these challenges. Most importantly, they benefit from a survey 
design process that combines expertise and experience over several years and multiple countries. All major constructs follow the OECD Oslo manual (OECD, 2005) on measuring innovation. Besides, pre-tests and pilot studies are run in multiple countries, industries and firms securing interpretability, reliability and validity (Laursen and Salter, 2006). All questionnaires are designed to provide response accuracy through the provision of detailed examples and definitions. The questionnaires contain long-hand questions so that the validity of central constructs can be checked. CIS surveys are administered via mail to avoid potential biases induced by telephone interviews (see for example Bertrand and Mullainathan, 2001) and entail significant non-response analyses. Finally and most importantly for this study, they provide information based on a harmonized survey process and questionnaire across multiple countries.

Besides, we inspect the database for potential issues arising from multicollinearity. We calculate correlations, variance inflation factors as well as condition indices and find no evidence for a high degree of multicollinearity by any conventionally applied standard (e.g., Chatterjee and Hadi, 2006). Appendix C and Appendix D provide full details.

\subsection{Variables}

\section{Dependent variable: Innovation performance}

Successful innovation activities can be defined along several dimensions which typically reflect different stages in the innovation value chain. The OECD Oslo Manual summarizes major approaches (OECD, 2005): Some studies focus on the provision of innovation inputs (e.g. R\&D expenditures or personnel), others on technological outputs (e.g. patents) and a third group on the economic impact (e.g. cost reductions, innovative products). We adopt an economic perspective by focussing on sales with new products (normalized by total sales) arguing that sales reflect the acceptance of a technologically new product by the market. What is more, literature has distinguished between different degrees of novelty. New products can be innovations because they are just new to the firm or to the market as a whole. The latter standard would imply that the product innovation is not just an imitation. We opt for this more stringent standard and choose the share of sales with market novelties ${ }^{1}$ as our dependent variable in line with several other studies in the field (see for example Laursen and Salter, 2006).

\section{Independent variables: Search strategies}

By their very nature, knowledge flows are difficult to capture. Several studies have relied on patent statistics (see for example Galunic and Rodan, 1998; Rosenkopf and Nerkar, 2001). However, patent statistics can only reflect particular knowledge flows and sources. Patenting activity is concentrated with dominant shares in relatively few sectors (such as

1 By definition this is a novelty on a firm's relevant market and not necessarily a "new to the world" innovation. 
pharmaceuticals) (e.g., Arundel and Kabla, 1998). Bloom and van Reenen (2002) provide an example and find that 72 percent of their sample of nearly 60,000 UK patents is owned by merely 12 companies. Significant portions of all inventions are not patented because of cost or disclosure considerations or cannot be patented because they do not fulfil the criteria of the patent offices (e.g., Encaoua et al., 2006; Griliches, 1979). In conclusion, the knowledge a firm may potentially search for can be expected to be much larger than the patented sub domain.

We follow a different approach by focusing on the knowledge sources which is in line with other recent research on search strategies (e.g., Grimpe and Sofka, 2009; Laursen and Salter, 2006). Respondents are provided with a wide list of knowledge sources and asked to rate their importance for the firms' innovation activities. The potential sources include: suppliers, customers, competitors, universities, research institutes, conferences (including professional exchanges and journal publications) and fairs. The importance rating is based on a four point Likert scale, ranging from "not relevant” to "highly important”. We will use these ordinal ratings of the seven potential knowledge sources for the identification of patterns of search strategies.

\section{Focus variables: $R \& D$ inputs}

Our research question goes beyond the identification of patterns in a firm's search strategies. We want to investigate the relationship between a firm's R\&D inputs and outputs given the choice of a certain pattern of search strategy. The central independent variable for this analysis is therefore a firm's investment into R\&D (normalized by sales). The complementary relationship between a firm's own R\&D investment and the acquisition of external knowledge is well established in the literature through the research stream on absorptive capacities (Cohen and Levinthal, 1989, 1990). While firms invest in their own R\&D, they establish also the absorptive capacity to identify, assimilate and exploit external knowledge. However, the generation of absorptive capacities requires the accumulation of knowledge over time through continuous R\&D engagements (e.g., van den Bosch et al., 1999). Accordingly, we add an additional dummy variable indicating whether $R \& D$ activities are performed on a continuous basis. This variable is often times interpreted as a proxy for firms having a dedicated R\&D department.

\section{Control variables}

Several other factors have been found to influence a firm's innovation success (for a comprehensive review see Ahuja et al., 2008). Most importantly, innovation activities have been linked to the availability of resources. Especially small firms have been found to suffer from liabilities of size because of constraints in the size and scope of their resource endowments. We add several control variables to the empirical model to capture these effects. First, we include the sales of a firm at the beginning of the reporting period (1998) in logs. Secondly, we add a dummy variable for whether the firm is part of a group and may draw from these resources. Third, firms differ in their degree of internationalisation. Hence, we incorporate the ratio of exports on overall sales. Finally, firms may direct their innovation 
activities towards refining processes which may limit the resource availability for product innovation. We therefore add a control dummy variable for whether the firm had process innovations.

Besides we control for remaining differences across countries and industries by including dummy variables. We generate industry dummies based on grouped two-digit industry classes following OECD and Eurostat practices. These include low-tech, medium low-tech, medium high-tech and high-tech manufacturing as well as low knowledge intensive and knowledge intensive services (Appendix E provides the detailed classification). Finally, our observations stem from various European countries. We therefore add country dummy variables.

\subsection{Estimation strategy and method}

We follow up on the theoretical discussion by using an inductive approach to investigate the research question. This approach has two major components. First, we apply a cluster analytical rationale of identifying subpopulations of firms with similar patterns of search strategies, i.e. search patterns. Second, we induce a regression rationale by investigating the relationship between $R \& D$ inputs and innovation performance given that a firm has chosen a particular search pattern. We choose a latent class analysis because it allows performing both estimation steps simultaneously.

Latent class approaches are part of the finite mixture model family. These models assume that a dataset consists of a finite number of distinct subpopulations. Members of a subpopulation are homogeneous within their group but heterogeneous between groups with regard to a predefined set of variables, such as their search behavior. These subpopulations (segments, groups, clusters or patterns) are latent in the sense that they are typically not observable but the probability of class membership can be estimated based on an underlying, continuous latent variable. Lazarsfeld (1950) pioneered the approach to identify survey response patterns. The identification of such distinct patterns is a primary focus of a latent class analysis which distinguishes it from other latent variable models (e.g. random-effects regression). Latent class analysis is based on a statistical model which helps to overcome major shortcomings of traditional cluster analyses: Measurements of fit can be calculated and significance tests performed (Jensen et al., 2007; Hagenaars and McCutcheon, 2002 provide a detailed discussion).

What is more, the cluster aspect of latent class analyses can be combined with regression analyses. Traditional regression analysis assumes homogeneity among all observations within a dataset. Latent class analyses, though, alleviates this assumption as homogeneity is only assumed for subsets of the database. A set of variables (so called covariates) can be defined that determines the conditional probability of an observation belonging to a particular subpopulation (i.e. a certain search patterns), while another set of variables (so-called predictors) influences the dependent variable (innovation performance). Therefore, the approach allows the identification of relationships between $R \& D$ inputs and innovation success given the conditional probability that the firm has chosen a certain search pattern. 
Both elements of our research question can be performed in one simultaneous estimation procedure.

The general probability structure is given as:

$$
f\left(y_{i} \mid z_{i}^{\text {cov }}, z_{i}^{\text {pred }}\right)=\sum_{x=1}^{K} P\left(x \mid z_{i}^{\text {cov }}\right) \prod_{t=1}^{T_{i}} f\left(y_{i t} \mid x, z_{i t}^{\text {pred }}\right),
$$

where the probability of outcome $y$ for observation $i$ depends upon the conditional probability of belonging to one of $K$ latent classes (with $x$ as the latent variable) based on a vector $z$ of covariate variables and a vector $z$ of predictors and $T$ replications of a single dependent variable.

This approach provides a tight fit with our research framework. We assume that the search strategies of firms can be condensed into a finite number of patterns (latent classes), depending upon their usage of external knowledge sources (covariates). Simultaneously, we can test for the existence of differences between the effects of R\&D inputs (predictors) on innovation success given a particular search pattern.

Besides, we opt for the estimation of latent class tobit regression models as a significant fraction of firms in the sample are not able to generate any sales from market novelties. Hence, the dependent variables contains more zeros than can be expected based on a univariate normal distribution. As a result, tobit models appear as the more appropriate choice. All estimations are carried out by relying on the algorithm provided by Vermunt and Magidson (2005). We estimate separate latent class tobit regression models for market and transition economies.

\section{$4 \quad$ Results}

\section{Descriptive analysis}

We start the discussion of the empirical results based on descriptive statistics. Table 2 provides descriptive statistics for firms' ratings on the importance of various external knowledge sources for their innovation activities in market and transition economies. In both environments customers are the most important source of knowledge followed by suppliers and/or trade fairs. Competitor knowledge follows in fourth place in transition economies slightly ahead of professional conferences while this relationship is reversed in market economies. 
Table 2: Descriptive statistics on search variables

\begin{tabular}{|c|c|c|c|c|c|}
\hline \multirow[t]{2}{*}{ Knowledge source } & \multicolumn{2}{|c|}{ Market economies } & \multicolumn{2}{|c|}{ Transition economies } & \multirow[t]{2}{*}{ Test of mean differences } \\
\hline & Mean & Std. Dev. & Mean & Std. Dev. & \\
\hline Suppliers & 1.62 & 1.10 & 1.58 & 1.07 & \\
\hline Customers & 1.63 & 1.15 & 1.85 & 1.09 & $\star \star \star *$ \\
\hline Competitors & 1.20 & 1.06 & 1.46 & 1.12 & $* * *$ \\
\hline Universities & 0.59 & 0.93 & 0.75 & 1.00 & $\star \star *$ \\
\hline Research institutes & 0.48 & 0.85 & 0.56 & 0.93 & $\star \star$ \\
\hline Conferences & 1.26 & 1.07 & 1.41 & 1.03 & $\star \star * *$ \\
\hline Fairs & 1.58 & 1.07 & 1.60 & 1.01 & \\
\hline No. of obs. & \multicolumn{2}{|c|}{2925} & \multicolumn{2}{|c|}{1594} & \\
\hline
\end{tabular}

*,**,*** indicate statistical significance at the $10 \%, 5 \%$ and $1 \%$ level;

Ratings range from 0 "not relevant” to 3 "highly important".

Academic knowledge from universities and research institutes has the lowest average ratings in both market and transition economies. This provides some evidence that this particular type of knowledge is often far from application and requires specific capabilities to absorb it (e.g., Perkmann and Walsh, 2007). We conduct tests on mean differences and find that external knowledge sources are in general significantly more important for firms in transition economies with the exception of suppliers and fairs. This is in line with the literature emphasizing the importance of scanning and absorptive capacity for firms facing institutional changes (May et al., 2000; Newman, 2000).

However, this can only be interpreted as initial evidence as firms in our sample differ along several dimensions between market and transitions economies (see Appendix $\mathrm{F}$ for full details). Firms in transition economies generate on average 12 percent of their sales from market novelties. This is slightly ahead of firms in market economies (11 percent). However, firms in market economies invest significantly more in $R \& D$ and are also more likely to engage in it continuously. This may reflect the availability of resources because these firms are also on average larger and more likely part of a group compared to firms in transition economies. Then again, the latter generate a larger portion of their sales ( 25 percent) from exports. Firms in market economies are significantly more likely to operate in medium and high-tech manufacturing (e.g. chemicals) while the share of firms in low knowledge-intensive services (e.g. transportation) is higher in transition economies. In conclusion, a multivariate analysis is required to separate the effects.

\section{Latent class analysis: Transition economies}

We start the discussion of the latent class tobit regression results by focussing on firms from transition economies. Latent class analyses are based on a statistical model. An assessment on the most appropriate number of classes of search patterns can therefore be based on criteria such as the Bayesian information criteria BIC or the Akaike information criteria AIC. The underlying rationale for choosing the model that minimizes these information criteria is the need for a parsimonious solution. On the one hand, each additional class increases the fit of the model as more heterogeneity is captured. In its extreme form each observation could be considered a unique class. On the other hand, specifying a multitude of classes reduces the opportunities for interpreting them meaningfully. BIC and AIC reflect this logic by correcting 
the goodness of fit of a model for the number of parameters that were necessary to estimate it. They differ in the weight that they assign to this "penalty" for additional parameters. In that sense, BIC has been found to be extremely rigid while AIC can be considered as rather liberal (McLachlan and Peel, 2000). Andrews and Currim (2003) provide a comparative study of several criteria and conclude that a modified version of AIC, so-called AIC3 ${ }^{2}$, performs best. We follow their advice.

We report all measurements of fit for a 1 to 6 class solution in Appendix A. The strong increase in model fit when moving away from a traditional regression analysis assuming homogeneity across all observations (1 class solution) provides further evidence for the existence of subpopulations with distinctive search patterns. AIC3 reaches its minimum for a 5 class model and can thus be considered to be the most appropriate model.

Table 3 provides the results for the identification of search patterns. We present these results separately from the tobit regressions in Table 4 for convenience in interpretation. However, it is important to note that we perform both estimations simultaneously. Classes of search patterns are sorted by size. 54 percent of all firms are assigned to class 1 , 24 percent to class 2 and 12 percent to class 3 . Classes 4 and 5 are relatively small, capturing just 5 percent and 4 percent of the sample respectively. Table 3 provides coefficients on the probability of a firm for being part of a specific class, i.e. having chosen a certain search pattern for external knowledge. We conduct Wald tests to identify significant differences. Significant differences arise from supplier, customer, university and trade fair knowledge. The importance of competitor, research institute and professional conference knowledge does not differ significantly between search patterns. This should not be misinterpreted as a lack of importance. The importance of these knowledge sources is just equally (or homogeneously) spread across all firms in the sample.

\footnotetext{
${ }^{2}$ AIC3 $=$ LogLikelihood -3 degrees of freedom
} 
Table 3: Model for latent classes for transition economies: Probabilities for class membership

\begin{tabular}{|c|c|c|c|c|c|c|}
\hline Search pattern & $\begin{array}{l}\text { Class1 } \\
\text { closed }\end{array}$ & $\begin{array}{c}\text { Class2 } \\
\text { market- } \\
\text { science } \\
\text { combinative }\end{array}$ & $\begin{array}{l}\text { Class3 } \\
\text { science } \\
\text { specific }\end{array}$ & $\begin{array}{c}\text { Class4 } \\
\text { open }\end{array}$ & $\begin{array}{l}\text { Class5 } \\
\text { diverse }\end{array}$ & Wald \\
\hline Suppliers & $\begin{array}{c}-0.26 \\
(0.09)\end{array}$ & $\begin{array}{c}-0.11 \\
(0.09)\end{array}$ & $\begin{array}{l}-0.22 \\
(0.10)\end{array}$ & $\begin{array}{c}0.56 \\
(0.23)\end{array}$ & $\begin{array}{c}0.04 \\
(0.19)\end{array}$ & $12.15^{* *}$ \\
\hline Customers & $\begin{array}{c}0.00 \\
(0.10)\end{array}$ & $\begin{array}{c}0.02 \\
(0.10)\end{array}$ & $\begin{array}{l}-0.11 \\
(0.12)\end{array}$ & $\begin{array}{c}0.47 \\
(0.19)\end{array}$ & $\begin{array}{l}-0.38 \\
(0.21)\end{array}$ & $8.26^{*}$ \\
\hline Competitors & $\begin{array}{c}0.17 \\
(0.09)\end{array}$ & $\begin{array}{c}0.05 \\
(0.10)\end{array}$ & $\begin{array}{c}0.17 \\
(0.11)\end{array}$ & $\begin{array}{c}0.00 \\
(0.16)\end{array}$ & $\begin{array}{l}-0.39 \\
(0.26)\end{array}$ & 4.03 \\
\hline Universities & $\begin{array}{c}-0.01 \\
(0.12)\end{array}$ & $\begin{array}{c}0.05 \\
(0.13)\end{array}$ & $\begin{array}{c}0.02 \\
(0.13)\end{array}$ & $\begin{array}{c}0.50 \\
(0.18)\end{array}$ & $\begin{array}{l}-0.56 \\
(0.38)\end{array}$ & $8.69 *$ \\
\hline Research institutes & $\begin{array}{c}0.03 \\
(0.10)\end{array}$ & $\begin{array}{c}0.06 \\
(0.11)\end{array}$ & $\begin{array}{c}0.01 \\
(0.12)\end{array}$ & $\begin{array}{l}-0.48 \\
(0.18)\end{array}$ & $\begin{array}{c}0.38 \\
(0.27)\end{array}$ & 7.62 \\
\hline Conferences & $\begin{array}{c}0.19 \\
(0.12)\end{array}$ & $\begin{array}{c}0.09 \\
(0.12)\end{array}$ & $\begin{array}{c}0.17 \\
(0.13)\end{array}$ & $\begin{array}{l}-0.06 \\
(0.19)\end{array}$ & $\begin{array}{l}-0.40 \\
(0.32)\end{array}$ & 3.04 \\
\hline Fairs & $\begin{array}{c}-0.21 \\
(0.10)\end{array}$ & $\begin{array}{c}0.00 \\
(0.10)\end{array}$ & $\begin{array}{l}-0.03 \\
(0.11)\end{array}$ & $\begin{array}{l}-0.20 \\
(0.18)\end{array}$ & $\begin{array}{c}0.45 \\
(0.21)\end{array}$ & $8.12 *$ \\
\hline Intercept & $\begin{array}{c}1.00 \\
(0.13) \\
\end{array}$ & $\begin{array}{c}0.90 \\
(0.13) \\
\end{array}$ & $\begin{array}{c}0.18 \\
(0.13) \\
\end{array}$ & $\begin{array}{l}-1.06 \\
(0.21) \\
\end{array}$ & $\begin{array}{l}-1.01 \\
(0.27) \\
\end{array}$ & $128.46 * * *$ \\
\hline No. of obs. & 860 & 386 & 197 & 85 & 66 & \\
\hline
\end{tabular}

Class 1, comprising more than half of all firms from the transition economies sample, has only negative coefficients across all significant knowledge sources (zero for customers). The search pattern of firms in this class is strongly below average for supplier as well as trade fair knowledge and slightly below average for university knowledge. We conclude that external knowledge sources are not a priority for firms choosing this search pattern. We will subsequently use the term "closed" search pattern for it. Firms in class 2 search primarily for knowledge from universities and customers while neglecting inputs from suppliers. It appears as if firms with this search pattern treat their search as an effort to combine the technological novelty of academic knowledge sources with the requirements specified by their clients. We will subsequently refer to this search pattern as "market-science combinative". Class 3 is more specific in the sense that firms focus predominantly on knowledge provided by universities. Knowledge provided by suppliers, customers or fairs is of less importance to them. This search pattern can therefore be termed "science specific". Although class 4 is fairly small, encompassing only 5 percent of all firms, it reflects the most aggressive search strategy for external knowledge. Firms with this search pattern give superior importance to knowledge from suppliers, e.g. through novel materials or equipment (Pavitt, 1984), combined with customer needs and university opportunities. The low importance of trade fair knowledge indicates that the search activities are fairly targeted at specific partners and not enriched by the broad spectrum of potential customers or suppliers that may be found at trade fairs. We will use the term "open” for the search pattern of firms in class 4 . The search pattern of firms in class 5 is equally specialized as only 4 percent in the sample choose it. Then again, it represents the opposite of the targeted approach described for class 4 . Firms in class 5 
benefit predominantly from the diverse knowledge that can be found at trade fairs and from suppliers. Hence, they draw value from the broad pool of potential customers and suppliers that can be found at trade fairs as opposed to developing specific relationships with only a few selected ones. This can be characterized as a "diverse" search strategy.

Table 4 presents the results of the latent class tobit regression. They encompass the conditional probability that a firm has chosen a certain search pattern. Again, the results presented in Table 3 and Table 4 have been estimated simultaneously. The results link innovation inputs and outputs for each search pattern. It cannot simply be assumed that more openness is also more beneficial for the firm. Both over- and undersearching have been found to have negative effects on innovation performance (Katila and Ahuja, 2002; Laursen and Salter, 2006). 
Table 4: Tobit regression for the share of turnover with market novelties in transition economies

\begin{tabular}{|c|c|c|c|c|c|c|c|}
\hline Search pattern & $\begin{array}{l}\text { Class1 } \\
\text { closed }\end{array}$ & $\begin{array}{c}\text { Class2 } \\
\text { market- } \\
\text { science } \\
\text { combinative }\end{array}$ & $\begin{array}{l}\text { Class3 } \\
\text { science } \\
\text { specific }\end{array}$ & $\begin{array}{l}\text { Class4 } \\
\text { open }\end{array}$ & $\begin{array}{l}\text { Class5 } \\
\text { diverse }\end{array}$ & Overall & $\begin{array}{l}\text { Wald(=) } \\
\text { Comp- } \\
\text { arison }\end{array}$ \\
\hline $\begin{array}{l}\text { R\&D exp. as share } \\
\text { of sales (ratio) }\end{array}$ & $\begin{array}{c}0.22 \\
(0.06)\end{array}$ & $\begin{array}{c}0.38 \\
(0.08)\end{array}$ & $\begin{array}{c}0.83 \\
(0.38)\end{array}$ & $\begin{array}{c}0.05 \\
(0.04)\end{array}$ & $\begin{array}{c}1.35 \\
(0.09)\end{array}$ & $273.04 * * *$ & 170.99*** \\
\hline $\begin{array}{l}\text { Continuous R\&D } \\
\text { (dummy) }\end{array}$ & $\begin{array}{c}0.04 \\
(0.01)\end{array}$ & $\begin{array}{c}0.08 \\
(0.02)\end{array}$ & $\begin{array}{c}0.16 \\
(0.05)\end{array}$ & $\begin{array}{c}0.02 \\
(0.02)\end{array}$ & $\begin{array}{l}-0.01 \\
(0.03)\end{array}$ & $41.59 * * *$ & $16.60 * * *$ \\
\hline $\begin{array}{l}\text { Export as share of } \\
\text { sales (ratio) }\end{array}$ & $\begin{array}{c}0.03 \\
(0.02)\end{array}$ & $\begin{array}{l}-0.08 \\
(0.02)\end{array}$ & $\begin{array}{c}0.03 \\
(0.07)\end{array}$ & $\begin{array}{c}0.24 \\
(0.02)\end{array}$ & $\begin{array}{l}-0.22 \\
(0.04)\end{array}$ & $244.53^{* * *}$ & $203.43 * * *$ \\
\hline Sales 1998 (logs) & $\begin{array}{l}-0.01 \\
(0.00)\end{array}$ & $\begin{array}{c}0.00 \\
(0.00)\end{array}$ & $\begin{array}{l}-0.06 \\
(0.01)\end{array}$ & $\begin{array}{l}-0.03 \\
(0.00)\end{array}$ & $\begin{array}{l}-0.10 \\
(0.01)\end{array}$ & $226.38 * * *$ & $164.06^{* * *}$ \\
\hline $\begin{array}{l}\text { Part of group } \\
\text { (dummy) }\end{array}$ & $\begin{array}{l}-0.06 \\
(0.05)\end{array}$ & $\begin{array}{c}0.07 \\
(0.03)\end{array}$ & $\begin{array}{c}0.47 \\
(0.14)\end{array}$ & $\begin{array}{l}-0.10 \\
(0.07)\end{array}$ & $\begin{array}{c}0.23 \\
(0.07)\end{array}$ & $75.66^{* * *}$ & $63.84 * * *$ \\
\hline $\begin{array}{l}\text { Process innovator } \\
\text { (dummy) }\end{array}$ & $\begin{array}{l}-0.02 \\
(0.01)\end{array}$ & $\begin{array}{l}-0.01 \\
(0.01)\end{array}$ & $\begin{array}{c}0.00 \\
(0.04)\end{array}$ & $\begin{array}{c}0.10 \\
(0.01)\end{array}$ & $\begin{array}{l}-0.23 \\
(0.02)\end{array}$ & $230.41^{* * *}$ & $217.47 * * *$ \\
\hline $\begin{array}{l}\text { Medium low-tech } \\
\text { manuf. (dummy) }\end{array}$ & $\begin{array}{c}0.00 \\
(0.01)\end{array}$ & $\begin{array}{c}0.02 \\
(0.02)\end{array}$ & $\begin{array}{l}-0.08 \\
(0.06)\end{array}$ & $\begin{array}{l}-0.01 \\
(0.02)\end{array}$ & $\begin{array}{c}0.15 \\
(0.03)\end{array}$ & $29.58 * * *$ & $27.57 * * *$ \\
\hline $\begin{array}{l}\text { Medium high-tech } \\
\text { manuf. (dummy) }\end{array}$ & $\begin{array}{c}0.01 \\
(0.01)\end{array}$ & $\begin{array}{c}0.02 \\
(0.02)\end{array}$ & $\begin{array}{c}0.06 \\
(0.07)\end{array}$ & $\begin{array}{c}0.15 \\
(0.02)\end{array}$ & $\begin{array}{c}0.31 \\
(0.02)\end{array}$ & $220.33^{* * *}$ & $147.27 * * *$ \\
\hline $\begin{array}{l}\text { High-tech manuf. } \\
\text { (dummy) }\end{array}$ & $\begin{array}{c}0.00 \\
(0.02)\end{array}$ & $\begin{array}{l}-0.01 \\
(0.03)\end{array}$ & $\begin{array}{c}0.07 \\
(0.10)\end{array}$ & $\begin{array}{c}0.52 \\
(0.02)\end{array}$ & $\begin{array}{l}-0.23 \\
(0.04)\end{array}$ & $538.32 * * *$ & $401.03 * * *$ \\
\hline $\begin{array}{l}\text { Low knowledge-int. } \\
\text { services (dummy) }\end{array}$ & $\begin{array}{c}0.01 \\
(0.01)\end{array}$ & $\begin{array}{c}0.01 \\
(0.02)\end{array}$ & $\begin{array}{c}0.07 \\
(0.06)\end{array}$ & $\begin{array}{l}-0.05 \\
(0.02)\end{array}$ & $\begin{array}{l}-0.18 \\
(0.04)\end{array}$ & $34.33 * * *$ & $28.99 * * *$ \\
\hline $\begin{array}{l}\text { Knowledge-int. } \\
\text { services (dummy) }\end{array}$ & $\begin{array}{l}-0.03 \\
(0.02)\end{array}$ & $\begin{array}{c}0.01 \\
(0.02)\end{array}$ & $\begin{array}{c}0.14 \\
(0.07)\end{array}$ & $\begin{array}{c}0.36 \\
(0.02)\end{array}$ & $\begin{array}{l}-0.08 \\
(0.04)\end{array}$ & $404.61^{* * *}$ & $313.79 * * *$ \\
\hline Estonia (dummy) & $\begin{array}{c}0.14 \\
(0.02)\end{array}$ & $\begin{array}{c}0.21 \\
(0.02)\end{array}$ & $\begin{array}{c}0.09 \\
(0.08)\end{array}$ & $\begin{array}{c}0.13 \\
(0.02)\end{array}$ & $\begin{array}{c}0.24 \\
(0.03)\end{array}$ & $206.01 * * *$ & $17.67 * * *$ \\
\hline Hungary (dummy) & $\begin{array}{c}-0.20 \\
(59.34)\end{array}$ & $\begin{array}{l}-0.01 \\
(0.02)\end{array}$ & $\begin{array}{l}-0.20 \\
(0.09)\end{array}$ & $\begin{array}{l}-0.23 \\
(0.02)\end{array}$ & $\begin{array}{c}0.53 \\
(0.03)\end{array}$ & $496.10^{* * *}$ & $495.59 * * *$ \\
\hline Lithuania (dummy) & $\begin{array}{c}0.03 \\
(0.03)\end{array}$ & $\begin{array}{c}0.04 \\
(0.02)\end{array}$ & $\begin{array}{c}0.17 \\
(0.05)\end{array}$ & $\begin{array}{c}0.24 \\
(0.01)\end{array}$ & $\begin{array}{l}-0.23 \\
(0.03)\end{array}$ & $372.32 * * *$ & $211.16^{* * *}$ \\
\hline Slovakia (dummy) & $\begin{array}{c}0.15 \\
(0.03)\end{array}$ & $\begin{array}{c}0.08 \\
(0.03)\end{array}$ & $\begin{array}{l}-0.02 \\
(0.12)\end{array}$ & $\begin{array}{c}0.19 \\
(0.02)\end{array}$ & $\begin{array}{c}0.04 \\
(0.03)\end{array}$ & $120.25^{* * *}$ & $24.87 * * *$ \\
\hline Intercept & $\begin{array}{l}-0.02 \\
(0.04)\end{array}$ & $\begin{array}{l}-0.07 \\
(0.07)\end{array}$ & $\begin{array}{c}1.09 \\
(0.20)\end{array}$ & $\begin{array}{c}0.24 \\
(0.06)\end{array}$ & $\begin{array}{c}1.60 \\
(0.13)\end{array}$ & $214.73^{* * *}$ & $198.17 * * *$ \\
\hline $\mathrm{R}^{2}$ & 0.88 & & & & & & \\
\hline
\end{tabular}

We conduct separate Wald tests on the coefficients being significantly different from zero (column "Wald overall" in Table 4) and whether they are significantly different between search patterns (column "Wald comparison"). This is the case for all variables in this model. The primary focus of the analysis is to explore the relationship between R\&D inputs and innovation performance, measured as share of sales with market novelties. We develop no a priori hypotheses for the control variables and discuss major effects from size, internationalization and sectors where they appear appropriate in the discussion of the relationship between search patterns, $R \& D$ and innovation output. The significant results for the control variables justify their inclusion in the empirical model. 
We find positive effects from both R\&D investment and continuous R\&D activities even in fairly closed search patterns. However, there are opportunities to improve this performance relationship once they move to a market-science combinative search pattern or even a science specific one. The latter provides the highest returns on continuously performing $R \& D$, reflecting the need to develop a shared understanding and sustained personal relationships with universities over time to benefit fully from their knowledge (Laursen and Salter, 2006). This may at times even require engaging in joint research projects where university and business researchers work side by side. This scientific knowledge, though, while providing high degrees of novelty, is often times far from application and needs to be further developed into market-ready products (Siegel et al., 2004). Hence, a science specific search pattern neglecting customer knowledge also appears to be more risky. This may explain while the more balanced market-science combinative search pattern is chosen by almost twice as many firms. However, the comparison of both search patterns provides support to other studies emphasizing that firms can improve their innovation performance by reducing the number of sources they are targeting (Katila and Ahuja, 2002; Laursen and Salter, 2006).

Our findings on the more specialized search patterns substantiate this line of argument. 5 percent of all firms in the sample adopt an aggressively open search pattern. Interestingly, R\&D investment is much less valuable in this search pattern. It even leads to a lower innovation performance compared to a closed search pattern. Judging from the control variables, this search pattern is valuable to firms that are highly active in international markets (export intensity) and operate in sectors with intensive technological dynamics, such as hightech manufacturing and knowledge intensive services. This dynamism in the technological and market environment provides a multitude of opportunities but also competitive pressures. However, we suspect that the additional dynamics induced by changes in the firm's institutional environment in transition economies amplify the negative effects from oversearching. The negative consequences from an overload of external ideas and impulses stem from an increasing risk of overlooking important trends, a decline of the overall quality in the evaluation of opportunities and subsequent flawed resource commitments (Koput, 1997). Skilled management competencies are relatively limited in transition economies (Makhija and Stewart, 2002). Hence, the threshold for the negative consequences of over-searching can be expected to be lower as suggested by the attention-based theory of the firm (Ocasio, 1997). The results for the open search pattern support this.

The results for the diverse search pattern provide an interesting contrast to the open search pattern. This group of firms in the sample appears to be rewarded for a short-term focus in their innovation strategy. They achieve the highest returns for their R\&D investment while continuous R\&D activities have even negative consequences. Firms that benefit from the diverse search pattern are typically smaller, focus on the domestic market (negative effect from export intensity) and predominantly active in low- and medium-tech manufacturing. Besides, they are much less likely to engage in process innovation. In sum, the underdeveloped product markets in transition economies (Wright et al., 2005) may provide an opening for a unique innovation strategy. Firms with a diverse search pattern appear to be able to invest relatively little in $\mathrm{R} \& \mathrm{D}$ for refining existing products to fit with local tastes and regulations. Their major inputs come from suppliers while their major sales channel is a 
broader audience of clients at trade fairs. In that sense, they are able to benefit from a unique market segment of pent-up demand for rather low-tech products which are considered standard in market economies.

There appear to be noteworthy differences between transition economies with firms from the Czech Republic serving as the comparison group. Especially firms in Hungary and Estonia benefit from diverse search patterns. Open search patterns are most beneficial in the Slovak Republic and Lithuania. Differences are less pronounced in the larger search pattern classes.

\section{Latent class analysis: Market economies}

We conduct the same latent class analysis for the market economies in our sample. Again, we rely on the AIC3 criterion to make the choice on the most appropriate model. It reaches its minimum for a 3-class model (see Appendix B for full details). This provides initial evidence for a larger variety of search patterns in transition economies. As before, we structure the discussion of the estimation results into a section on the identification of search patterns (Table 5) and a section on the regression results (Table 6). We emphasize again that both tables stem from simultaneous estimation.

Table 5: Model for latent classes for established economies: Probabilities for class membership

\begin{tabular}{|c|c|c|c|c|}
\hline Search pattern & $\begin{array}{c}\text { Class1 } \\
\text { competitor driven }\end{array}$ & $\begin{array}{c}\text { Class2 } \\
\text { customer driven }\end{array}$ & $\begin{array}{c}\text { Class3 } \\
\text { market-science } \\
\text { combinative }\end{array}$ & Wald \\
\hline Suppliers & $\begin{array}{c}0.04 \\
(0.04)\end{array}$ & $\begin{array}{c}0.00 \\
(0.06)\end{array}$ & $\begin{array}{l}-0.04 \\
(0.06)\end{array}$ & 1.18 \\
\hline Customers & $\begin{array}{l}-0.13 \\
(0.04)\end{array}$ & $\begin{array}{c}0.04 \\
(0.07)\end{array}$ & $\begin{array}{c}0.09 \\
(0.07)\end{array}$ & $8.97 * *$ \\
\hline Competitors & $\begin{array}{c}0.17 \\
(0.05)\end{array}$ & $\begin{array}{l}-0.16 \\
(0.07)\end{array}$ & $\begin{array}{c}0.00 \\
(0.06)\end{array}$ & $11.68^{* * *}$ \\
\hline Universities & $\begin{array}{c}0.04 \\
(0.06)\end{array}$ & $\begin{array}{c}0.03 \\
(0.08)\end{array}$ & $\begin{array}{l}-0.07 \\
(0.08)\end{array}$ & 0.95 \\
\hline Research institutes & $\begin{array}{l}-0.03 \\
(0.05)\end{array}$ & $\begin{array}{l}-0.13 \\
(0.07)\end{array}$ & $\begin{array}{c}0.16 \\
(0.08)\end{array}$ & $4.52 *$ \\
\hline Conferences & $\begin{array}{l}-0.06 \\
(0.05)\end{array}$ & $\begin{array}{c}0.13 \\
(0.08)\end{array}$ & $\begin{array}{l}-0.07 \\
(0.08)\end{array}$ & 2.80 \\
\hline Fairs & $\begin{array}{l}-0.13 \\
(0.05)\end{array}$ & $\begin{array}{c}0.03 \\
(0.07)\end{array}$ & $\begin{array}{c}0.11 \\
(0.08)\end{array}$ & $8.17 * *$ \\
\hline Intercept & $\begin{array}{c}0.41 \\
(0.14)\end{array}$ & $\begin{array}{l}-0.17 \\
(0.22)\end{array}$ & $\begin{array}{l}-0.24 \\
(0.19)\end{array}$ & $9.41^{* * *}$ \\
\hline No. of obs. & 1801 & 376 & 748 & \\
\hline
\end{tabular}

Table 5 provides an overview on the probabilities for membership in a group of firms with homogeneous search patterns. Similarities and differences with the structure of search patterns emerge when we conduct Wald tests on significance. Search patterns vary 
significantly in whether they are based on customer, competitor, research institute or trade fair knowledge. Suppliers and universities are not irrelevant but make no significant difference for the classification of search patterns. This is especially interesting as firms appear to be relatively homogeneous in their knowledge sourcing from universities but differ in the way in which they make use of research institutes. This is in stark contrast to the findings for transition economies and may reflect the deficits in the availability of research institutes for technology transfer (such as the Fraunhofer Society in Germany) in transition economies.

Another important difference in the structure of search patterns in market economies compared to transition economies is the lack of a search pattern with strictly negative, significant coefficients. Such consistently low ratings for external knowledge sources have been interpreted as a closed search pattern in transition economies. It cannot be identified in market economies. Instead, firms in market economies follow at least one major direction in their search strategies. For the majority of firms (62 percent of the sample) in class 1 the most important knowledge stems from competitors while they are very unlikely to benefit from customer, trade fair or research institute knowledge. This hints towards an innovation strategy that is largely self-contained but includes competitor reconnaissance as a major element. Competitors operate in a similar market and technology environment which make their inputs immediately relevant and easy to absorb (Dussauge et al., 2000). On the one hand, this enables firms to benefit from fast follower advantages, such as to free-ride on the pioneer's investments in establishing new market segments (Dos Santos and Peffers, 1995). On the other hand, it may limit the firm to imitation in its R\&D activities with fewer opportunities to capture economic rents in an at least initially uncontested market (Grimpe and Sofka, 2009). We will refer to the search pattern of class 1 firms as "competitor driven”. Further, 13 percent of firms in the sample choose the search pattern of class 2. It focuses also on the market side but with strong emphasis on knowledge from customers and trade fairs while competitors are of much less importance. In that sense, the search pattern can be characterized as "customer driven”. Finally, 26 percent of firms in class 3 choose a search pattern that combines both customer and trade fair knowledge with inputs from research institutes. It is the most open of all search patterns of firms in market economies but resembles more closely the marketscience combinative search pattern identified for transition economies. We will use this term for class 3.

Again, we compare these search patterns based on the relationship between R\&D inputs and innovation success. Table 6 details the second part of the simultaneous latent class tobit regression. 
Table 6: Tobit regression for the share of turnover with market novelties in established economies

\begin{tabular}{|c|c|c|c|c|c|}
\hline Search pattern & $\begin{array}{c}\text { Class1 } \\
\text { competitor } \\
\text { driven }\end{array}$ & $\begin{array}{l}\text { Class2 } \\
\text { customer } \\
\text { driven }\end{array}$ & $\begin{array}{c}\text { Class3 } \\
\text { market- } \\
\text { science } \\
\text { combinative }\end{array}$ & $\begin{array}{c}\text { Wald } \\
\text { Overall }\end{array}$ & $\begin{array}{c}\text { Wald(=) } \\
\text { Comparison }\end{array}$ \\
\hline $\begin{array}{l}\text { R\&D exp. as share } \\
\text { of sales (ratio) }\end{array}$ & $\begin{array}{c}0.13 \\
(0.04)\end{array}$ & $\begin{array}{c}0.45 \\
(0.38)\end{array}$ & $\begin{array}{c}0.42 \\
(0.12)\end{array}$ & $33.37 * * *$ & $8.38 * *$ \\
\hline $\begin{array}{l}\text { Continuous R\&D } \\
\text { (dummy) }\end{array}$ & $\begin{array}{c}0.08 \\
(0.01)\end{array}$ & $\begin{array}{c}0.15 \\
(0.05)\end{array}$ & $\begin{array}{c}0.05 \\
(0.02)\end{array}$ & $66.50 * * *$ & 4.44 \\
\hline $\begin{array}{l}\text { Export as share of } \\
\text { Sales (ratio) }\end{array}$ & $\begin{array}{c}0.04 \\
(0.02)\end{array}$ & $\begin{array}{c}0.15 \\
(0.09)\end{array}$ & $\begin{array}{c}0.02 \\
(0.04)\end{array}$ & $8.57 * *$ & 1.47 \\
\hline Sales 1998 (logs) & $\begin{array}{c}0.01 \\
(0.00)\end{array}$ & $\begin{array}{l}-0.04 \\
(0.01)\end{array}$ & $\begin{array}{l}-0.02 \\
(0.01)\end{array}$ & $50.53 * * *$ & $43.43 * * *$ \\
\hline $\begin{array}{l}\text { Part of group } \\
\text { (dummy) }\end{array}$ & $\begin{array}{c}0.05 \\
(0.02)\end{array}$ & $\begin{array}{l}-0.11 \\
(0.10)\end{array}$ & $\begin{array}{l}-0.04 \\
(0.04)\end{array}$ & $10.74^{* * *}$ & $7.55^{* *}$ \\
\hline $\begin{array}{l}\text { Process innovator } \\
\text { (dummy) }\end{array}$ & $\begin{array}{l}-0.02 \\
(0.01)\end{array}$ & $\begin{array}{l}-0.05 \\
(0.04)\end{array}$ & $\begin{array}{c}0.01 \\
(0.02)\end{array}$ & 4.51 & 2.83 \\
\hline $\begin{array}{l}\text { Medium low-tech } \\
\text { manuf. (dummy) }\end{array}$ & $\begin{array}{c}0.01 \\
(0.02)\end{array}$ & $\begin{array}{l}-0.05 \\
(0.06)\end{array}$ & $\begin{array}{c}0.01 \\
(0.03)\end{array}$ & 0.84 & 0.84 \\
\hline $\begin{array}{l}\text { Medium high-tech } \\
\text { manuf. (dummy) }\end{array}$ & $\begin{array}{l}-0.01 \\
(0.02)\end{array}$ & $\begin{array}{l}-0.04 \\
(0.06)\end{array}$ & $\begin{array}{c}0.03 \\
(0.03)\end{array}$ & 1.14 & 1.14 \\
\hline $\begin{array}{l}\text { High-tech manuf. } \\
\text { (dummy) }\end{array}$ & $\begin{array}{c}0.03 \\
(0.02)\end{array}$ & $\begin{array}{l}-0.07 \\
(0.10)\end{array}$ & $\begin{array}{c}0.02 \\
(0.05)\end{array}$ & 2.69 & 1.55 \\
\hline $\begin{array}{l}\text { Low knowledge-int. } \\
\text { services (dummy) }\end{array}$ & $\begin{array}{c}0.01 \\
(0.03)\end{array}$ & $\begin{array}{c}0.08 \\
(0.08)\end{array}$ & $\begin{array}{c}0.00 \\
(0.04)\end{array}$ & 1.26 & 0.65 \\
\hline $\begin{array}{l}\text { Knowledge-int. } \\
\text { services (dummy) }\end{array}$ & $\begin{array}{c}0.04 \\
(0.01)\end{array}$ & $\begin{array}{c}0.08 \\
(0.07)\end{array}$ & $\begin{array}{c}0.00 \\
(0.04)\end{array}$ & $10.09 * *$ & 1.55 \\
\hline Germany (dummy) & $\begin{array}{c}0.02 \\
(0.02)\end{array}$ & $\begin{array}{l}-0.06 \\
(0.09)\end{array}$ & $\begin{array}{c}0.06 \\
(0.03)\end{array}$ & 5.74 & 1.77 \\
\hline Greece (dummy) & $\begin{array}{l}-0.51 \\
(0.08)\end{array}$ & $\begin{array}{c}0.19 \\
(0.10)\end{array}$ & $\begin{array}{l}-0.02 \\
(0.06)\end{array}$ & $52.00 * * *$ & $30.99 * * *$ \\
\hline Portugal (dummy) & $\begin{array}{c}0.03 \\
(0.02)\end{array}$ & $\begin{array}{c}0.14 \\
(0.09)\end{array}$ & $\begin{array}{c}0.06 \\
(0.04)\end{array}$ & $8.12^{* *}$ & 1.85 \\
\hline Spain (dummy) & $\begin{array}{c}0.00 \\
(0.02)\end{array}$ & $\begin{array}{c}0.18 \\
(0.08)\end{array}$ & $\begin{array}{c}0.07 \\
(0.03)\end{array}$ & $16.37 * * *$ & $8.75^{* * *}$ \\
\hline Intercept & $\begin{array}{c}-0.31 \\
(0.05)\end{array}$ & $\begin{array}{c}0.69 \\
(0.27)\end{array}$ & $\begin{array}{c}0.26 \\
(0.14)\end{array}$ & $73.77 * * *$ & $50.46 * * *$ \\
\hline 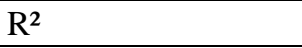 & 0.57 & 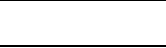 & 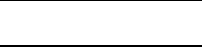 & & \\
\hline
\end{tabular}

As in the transition economies case, the "overall" column provides statistics on the significance of the coefficient of a particular variable while the "comparison" column provides significance tests on whether these differ between search patterns. We find an interesting distinction here because performing $R \& D$ activities continuously has a significant and positive effect on sales with market novelties. However, this effect is not significantly different across different search patterns. We suspect that the resource availabilities for having a dedicated $R \& D$ department for continuous activities are not as much a differentiating factor in market economies as they are in transition ones. 
Firms can achieve positive returns on their R\&D investment given a competitor driven search pattern. However, the returns are the lowest across all search patterns. This may reflect the limited opportunities for differentiation given a search pattern that is so closely influenced by competitors. The returns on $\mathrm{R} \& \mathrm{D}$ investment are the highest given a customer driven search pattern even though the effect from a market-science combinative search pattern comes close. As for the transition economies, we find that a broader search strategy (the marketscience combinative pattern) does not necessarily perform better. Industry differences are not significant or not significantly different across search patterns. Interestingly, firms with limited resources perform better choosing one of the two search patterns. Their value decreases with growing firm size and companies developing into groups. We suspect that smaller firms benefit more from the inputs of customers, fairs and/or research institutes because of their organizational flexibility (e.g., Autio et al., 2000). The transformation and assimilation of external knowledge with existing knowledge stocks has been identified as a major barrier (Todorova and Durisin, 2007). Small firms with the same person or a small core team being in charge of both $\mathrm{R} \& \mathrm{D}$ and marketing decisions may experience much lower transaction costs for the management of the external knowledge inflow.

Differences in the choice between a customer-driven or a market-science combinative search pattern may be explained with the availability of an infrastructure of research institutes in the firm's national environment. Firms in high-technology environments such as Germany and Belgium (the reference group of the estimation) are much more likely to benefit from market-science combinative search patterns while the firms in less technologically advanced market economies in the sample (Greece, Portugal, Spain) are less likely to do so.

\section{$5 \quad$ Discussion}

We conduct this study at the intersection between the literature streams of institutional change and search strategies for external knowledge. On the one hand, we respond to the call in the literature for more insights into how firms move from reactive flexibility in times of pronounced institutional transition towards achieving competitive advantage by building unique resources (Hoskisson et al., 2000). On the other hand, we add the additional layer of institutional infrastructures for innovation to the discussion on firm's search strategies which have been primarily tested in institutionally stable market environments such as the U.S. or the U.K. (e.g., Katila and Ahuja, 2002; Laursen and Salter, 2006; Rosenkopf and Nerkar, 2001). Our inductive study based on a broad, harmonized dataset allows us to compare search strategies and performance implications for both transition and market economies. Conclusions can be drawn for scholarly discussion as well as management and policy maker discourse.

\section{Implications for research}

Institutional theory on transition economies has emphasized the need for scanning and absorptive capacity for firms to succeed during institutional change (May et al., 2000; 
Newman, 2000). Such capabilities enable them to react flexibly to changes in institutional opportunities and challenges. We go one step further and describe these search strategies for external knowledge along patterns of innovation sources that are targeted. In fact, our research reveals interesting differences between these search patterns in market and transition economies.

First, we find that search patterns in transition economies are more diverse than in established market economies. On the one hand, this may reflect a heightened degree of uncertainty about where to search for external knowledge and how intensively it should be conducted. On the other hand, the institutional change might result in a huge variety of opportunities that firms can exploit. However, the majority of firms in transition economies is still following a closed search strategy. We argue that this is due to the specificity of inputand output-relationships during the planned economy era which did not reward active search for external knowledge at the firm level (Blanchard and Kremer, 1997). Hence, the management capabilities for active external search are not well developed. Secondly, promising patterns for firms in transition economies can be identified. We find evidence for both the negative effects of under- and over-searching. Firms in transition economies can improve the returns from their own $R \& D$ investment by searching for valuable knowledge from universities. The effects are lower but still positive if they extend these search patterns towards customer knowledge. This can be seen as a promising route if firms lack the necessary internal knowledge stock and personal relationships with university scientists to benefit meaningfully from their research. However, if firms in transition economies choose even more extensive search strategies the performance effects drop even further. We conclude that open innovation in transition economies is a fairly focused process. It may easily overload scarce competencies for managing the search and subsequent absorption processes (Ocasio, 1997). The institutional dynamics can therefore be seen as facilitating search strategies that are much more narrowly focused compared with firms in market economies. Firms still benefit from incorporating external knowledge into their external R\&D activities. However, they reach the threshold for oversearching much earlier. Thirdly, we find that opportunities to benefit from catch-up demand in underdeveloped product markets in transition economies still exist as a niche strategy. This strategy provides high returns for own R\&D investments by channelling knowledge from suppliers quickly and selling the products to broader customer segments. In that sense, the institutional change has created an opportunity for the success of a specific search pattern.

For market economies, our results also provide insights that extend existing findings on the breadth and depth of a firm's search strategy (Katila and Ahuja, 2002; Laursen and Salter, 2006). The identification of patterns in firms' search strategies enables us to draw distinctions between the performance effects of different knowledge sources. Most importantly, search strategies that are narrowly targeted at competitors limit the firm's potential for innovation success beyond imitation. They can be more successful by focussing their search on customer and/or science knowledge. This provides an interesting link to the findings for transition economies. In both institutional settings, search strategies combining customer with academic knowledge appear as a promising open innovation strategy. However, the opportunities to deviate from this search strategy through specialization are stronger in transition economies. 


\section{Implications for management practice and policy making}

Our results have also major implications for how managers should structure their search for external knowledge as well as for policy makers in facilitating the growth of valuable external knowledge pools. We find that certain patterns of search strategies perform better than others. However, for innovation managers this implies not just a change in the direction of their search but also the build-up of underlying competencies and organizational routines. We find that there is both a need for openness as well as a need for focus in these activities especially in transition economies. While the academic landscape may still be comparatively underdeveloped in transition economies, it provides the most fruitful route. Firms should actively scan and scout for leading university research in their environment and develop long term relationships. This may include hiring key university scientists or collocating R\&D centers to benefit fully from an in-depth exchange of knowledge. Besides, they should proceed cautiously with extending these search strategies to other sources. With respect to public policy support in transition economies, policy makers should be encouraged to strengthen the academic infrastructure and increase the opportunities for technology transfer. Targeted R\&D subsidies, awarded conditionally on a joint project between academia and industry, could be an appropriate policy tool. Moreover, it is not only the formal technology transfer but also the informal linkages that matter. Both have been shown to be complementary (Grimpe and Hussinger, 2008) which suggests that public policy should not neglect strengthening the informal ties between firms and universities. In market economies, though, our results indicate that innovation management needs to move away from a myopic focus on competitors as a search strategy. In that sense, we provide additional support for the idea of a market-driven organization that focuses on anticipatory demand from leading customers (Slater and Narver, 1999).

\section{Concluding remarks}

Our analysis benefits from the unique opportunity to assemble innovation survey data across national and industry boundaries. There are, however, also some shortcomings of our study regarding country coverage and dynamic relationships. First, the availability of country data for all EU member states that participated in CIS-3 is limited. This applies particularly to large economies like France, Italy or the Netherlands. Adding observations from these countries would provide an improved basis for our reasoning. It depends on the member states to provide access to the micro-data that needs to be treated subsequently by Eurostat in order to be released. Second, it would be most interesting to study the dynamic relationship, i.e. changes in the search behavior of firms. Although results from CIS-4 are already available in a tabulated form there is no possibility to merge two or more waves of CIS to yield a panel structure of the data without violating the data confidentiality requirements that have to be implemented by Eurostat. An alternative approach could hence be to focus just on a few countries for which micro-data is available as a panel, e.g. Germany. This could provide some interesting results regarding the evolution of search patterns in relation to certain company characteristics. Besides the focus on European countries it would also be interesting to compare results with other major economies like the U.S. or Japan. Different administrative, 
cultural and historical backgrounds would enhance our understanding of how firms interact with their environment, how institutional infrastructures for innovation shape the search behavior, and what differentiates actual from best practices. 


\section{References}

Ahuja, G., C.M. Lampert and V. Tandon (2008), Moving Beyond Schumpeter: Management Research on the Determinants of Technological Innovation, The Academy of Management Annals 2, 1 - 98.

Andrews, R.L. and I.S. Currim (2003), A Comparison of Segment Retention Criteria for Finite Mixture Logit Models, Journal of Marketing Research (JMR) 40 (2), 235-243.

Arrow, K.J. (1962), Economic Welfare and the Allocation of Resources for Invention, in: Nelson, R. R. (ed.) The Rate and Direction of Inventive Activity: Economic and Social Factors, Princeton, NJ, 609-625.

Arundel, A. and I. Kabla (1998), What Percentage of Innovations Are Patented? Empirical Estimates for European Firms, Research Policy 27, 127-141.

Autio, E., H.J. Sapienza and J.G. Almeida (2000), Effects of Age at Entry, Knowledge Intensity, and Imitability on International Growth, Academy of Management Journal 43 (5), 909-924.

Bertrand, M. and S. Mullainathan (2001), Do People Mean What They Say? Implications for Subjective Survey Data, American Economic Review 91 (2), 67-72.

Blanchard, O. and M. Kremer (1997), Disorganization, Quarterly Journal of Economics 112 (4), 1091-1126.

Bloom, N. and J. Van Reenen (2002), Patents, Real Options and Firm Performance, Economic Journal 112 (478), C97-C116.

Calantone, R.J., J.B. Schmidt and C.A. Di Benedetto (1997), New Product Activities and Performance: The Moderating Role of Environmental Hostility., Journal of Product Innovation Management 14 (3), 179-189.

Cassiman, B. and R. Veugelers (2006), In Search of Complementarity in the Innovation Strategy: Internal R\&D and External Knowledge Acquisition, Management Science 52 (1), 68-82.

Chang, S.-J., C.-N. Chung and I.P. Mahmood (2006), When and How Does Business Group Affiliation Promote Firm Innovation? A Tale of Two Emerging Economies, Organization Science 17 (5), 637-656.

Chatterjee, S. and A.S. Hadi (2006), Regression Analysis by Example, New York.

Chesbrough, H.W. (2003), Open Innovation: The New Imperative for Creating and Profiting from Technology, Cambridge (MA).

Cohen, W.M. and D.A. Levinthal (1989), Innovation and Learning: The Two Faces of R\&D, The Economic Journal 99 (397), 569-596.

Cohen, W.M. and D.A. Levinthal (1990), Absorptive Capacity: A New Perspective on Learning and Innovation, Administrative Science Quarterly 35 (1), 128-152.

Criscuolo, C., J.E. Haskel and M.J. Slaughter (2005), Global Engagement and the Innovation Activities of Firms, NBER Working Paper No. 11479, Cambridge, MA.

Danis, W.M., D.S. Chiaburu and M.A. Lyles (2009), The Impact of Managerial Networking Intensity and Market-Based Strategies on Firm Growth During Institutional Upheaval: A Study of Small and Medium-Sized Enterprises in a Transition Economy, Journal of International Business Studies advance online publication, DOI:10.1057/jibs.2009.45.

Dos Santos, B.L. and K. Peffers (1995), Rewards to Investors in Innovative Information Technology Applications: First Movers and Early Followers in Atms, Organization Science 6 (3), 241-259. 
Dussauge, P., B. Garrette and W. Mitchell (2000), Learning from Competing Partners: Outcomes and Duration of Scale and Link Alliances in Europe, North America and Asia., Strategic Management Journal 21 (2), 99-126.

Dyer, J.H. and N.W. Hatch (2006), Relation-Specific Capabilities and Barriers to Knowledge Transfers: Creating Advantage through Network Relationships, Strategic Management Journal 27 (8), 701-719.

Edquist, C. (1997), Systems of Innovation: Technologies, Institutions, and Organizations, New York.

Encaoua, D., D. Guellec and C. Martinez (2006), Patent Systems for Encouraging Innovation: Lessons from Economic Analysis, Research Policy 35 (9), 1423-1440.

Eurostat (2005), Community Innovation Survey Light (Cis Light), http://europa.eu.int/estatref/info/sdds/de/inn/inn_cisl_sm.htm No., Luxemburg.

Frosch, R.A. (1996), The Customer for R\&D Is Always Wrong!, Research Technology Management 39 (6), 22-25.

Galunic, C.D. and S. Rodan (1998), Resource Recombinations in the Firm: Knowledge Structures and the Potential for Schumpeterian, Strategic Management Journal 19 (12), 1193-1201.

Gelbuda, M., K.E. Meyer and A. Delios (2008), International Business and Institutional Development in Central and Eastern Europe, Journal of International Management 14, 1-11.

Grant, R.M. (1996), Toward a Knowledge-Based Theory of the Firm, Strategic Management Journal 17, 109-122.

Griliches, Z. (1979), Issues in Assessing the Contribution of Research and Development to Productivity Growth, Bell Journal of Economics 10 (1), 92-116.

Grimpe, C. and K. Hussinger (2008), Formal and Informal Technology Transfer from Academia to Industry: Complementarity Effects and Innovation Performance, ZEW Discussion Paper No. 08-080, Mannheim.

Grimpe, C. and W. Sofka (2009), Search Patterns and Absorptive Capacity: Low- and HighTechnology Sectors in European Countries, Research Policy 38, 495-506.

Guan, J.C., R.C.M. Yam, E.P.Y. Tang and A.K.W. Laud (2009), Innovation Strategy and Performance During Economic Transition: Evidences in Beijing, China, Research Policy 38, 802-812.

Hagenaars, J.A. and A.L. McCutcheon (2002), Applied Latent Class Analysis, Cambridge.

Hall, B.H., A.B. Jaffe and M. Trajtenberg (2001), The Nber Patent Citation Data File: Lessons, Insights and Methodological Tools, NBER Working Paper No. 8498, Cambridge, MA.

Hall, B.H., A.N. Link and J.T. Scott (2003), Universities as Research Partners, Journal of Economic Studies 85, 485-491.

Hoskisson, R.E., L. Eden, C.M. Lau and M. Wright (2000), Strategy in Emerging Economies, Academy of Management Journal 43, 249-267.

Ingram, P. and K. Clay (2000), The Choice-within-Constraints New Institutionalism and Implications for Sociology, Annual Review of Sociology 26 (1), 525-546.

Jackson, G. and R. Deeg (2008), Comparing Capitalisms: Understanding Institutional Diversity and Its Implications for International Business, Journal of International Business Studies 39 (4), 540-561.

Jaffe, A.B. (1986), Technological Opportunity and Spillovers of R\&D: Evidence from Firms' Patents, Profits, and Market Values, American Economic Review 76 (5), 984-1001.

Jansen, J.J.P., F.A.J. Van Den Bosch and H.W. Volberda (2006), Exploratory Innovation, Exploitative Innovation, and Performance: Effects of Organizational Antecedents and Environmental Moderators, Management Science 52 (11), 1661-1674. 
Jensen, M.B., B. Johnson, E. Lorenz and B.A. Lundvall (2007), Forms of Knowledge and Modes of Innovation, Research Policy 36 (5), 680-693.

Katila, R. (2002), New Product Search over Time: Past Ideas in Their Prime?, Academy of Management Journal 45, 995-1010.

Katila, R. and G. Ahuja (2002), Something Old, Something New: A Longitudinal Study of Search Behavior and New Product Introduction, Academy of Management Journal 45 (6), 1183-1194.

Kogut, B. (1991), Country Capabilities and the Permeability of Borders, Strategic Management Journal 12, 33-48.

Koput, K.W. (1997), A Chaotic Model of Innovative Search: Some Answers, Many Questions, Organization Science 8 (5), 528-542.

Krammer, S.M.S. (2009), Drivers of National Innovation in Transition: Evidence from a Panel of Eastern European Countries, Research Policy 38, 845-860.

Lane, P.J., B.R. Koka and S. Pathak (2006), The Reification of Absorptive Capacity: A Critical Review and Rejuvenation of the Construct, Academy of Management Review 31 (4), 833-863.

Lane, P.J. and M. Lubatkin (1998), Relative Absorptive Capcity and Inter-Organizational Learning., Strategic Management Journal 19, 461-477.

Laursen, K. and A. Salter (2006), Open for Innovation: The Role of Openness in Explaining Innovation Performance among U.K. Manufacturing Firms, Strategic Management Journal 27, 131-150.

Lazarsfeld, P.F. (1950), The Logical and Mathematical Foundations of Latent Structure Analysis, in: Stouffer, S. A. (ed.) Measurement and Prediction, Volume Iv of the American Soldier: Studies in Social Psychology in World War Ii, Princeton, 362-412.

Liebeskind, J.P. (1996), Knowledge, Strategy, and the Theory of the Firm, Strategic Management Journal 17, 93-107.

Liebeskind, J.P. (1997), Keeping Organizational Secrets: Protective Institutional Mechanisms and Their Costs, Industrial \& Corporate Change 6 (3), 623-663.

Link, A.N. and J.T. Scott (2005), Universities as Partners in U.S. Research Joint Ventures, Research Policy 34, 385-393.

Lundvall, B.A. ed. (1992), National Systems of Innovation. Towards a Theory of Innovation and Interactive Learning, London.

Mahmood, I.P. and W. Mitchell (2004), Two Faces: Effects of Business Groups on Innovation in Emerging Economies, Management Science 50 (10), 1348-1365.

Makhija, M.V. and A.C. Stewart (2002), The Effect of National Context on Perceptions of Risk: A Comparison of Planned Versus Free-Market Managers, Journal of International Business Studies 33 (4), 737-756.

May, R.C., W.H. Stewart Jr and R. Sweo (2000), Environmental Scanning Behavior in a Transitional Economy: Evidence from Russia, Academy of Management Journal 43 (3), 403-427.

McLachlan, G. and D. Peel (2000), Finite Mixture Models, New York.

Meyer, K.E., S. Estrin, S.K. Bhaumik and M.W. Peng (2009), Institutions, Resources, and Entry Strategies in Emerging Economies, Strategic Management Journal 30, 61-80.

Meyer, K.E. and M. Gelbuda (2006), Process Perspectives in International Business Research, Management International Review 46, 143-164.

Meyer, K.E. and M.W. Peng (2005), Probing Theoretically into Central and Eastern Europe: Transactions, Resources, and Institutions, Journal of International Business Studies 36 (6), 600-621.

Murtha, T.P. and S.A. Lenway (1994), Country Capabilities and the Strategic State: How National Political Institutions Affect Multinational Corporations' Strategies, Strategic Management Journal 15, 113-129. 
Nelson, R.R. and N. Rosenberg (1993), Technical Innovation and National Systems, in: Nelson, R. R. (ed.) National Innovation Systems: A Comparative Analysis, New York, 3-22.

Newman, K.L. (2000), Organizational Transformation During Institutional Upheaval, Academy of Management Review 25 (3), 602-619.

North, D. (1990), Institutions, Institutional Change and Economic Performance, Cambridge.

Ocasio, W. (1997), Towards an Attention-Based View of the Firm, Strategic Management Journal 18, 187-206.

OECD (2005), Oslo Manual: Guidelines for Collecting and Interpreting Innovation Data, Paris.

Ojah, K. and L. Monplaisir (2003), Investors' Valuation of Global Product Design and Development, Journal of International Business Studies 34, 457-472.

Pavitt, K. (1984), Sectoral Patterns of Technical Change: Towards a Taxonomy and a Theory, Research Policy 13 (6), 343-373.

Peng, M.W. (2003), Institutional Transitions and Strategic Choices, Academy of Management Review 28 (2), 275-296.

Perkmann, M. and K. Walsh (2007), University-Industry Relationships and Open Innovation: Towards a Research Agenda, International Journal of Management Reviews 9 (4), 259-280.

Radosevic, S. (1998), The Transformation of National Systems of Innovation in Eastern Europe: Between Restructuring and Erosion, Industrial \& Corporate Change 7 (1), 77-108.

Radosevic, S. and L. Auriol (1999), Patterns of Restructuring in Research, Development and Innovation Activities in Central and Eastern European Countries: An Analysis Based on S\&T Indicators, Research Policy 28, 351-376.

Rosenkopf, L. and A. Nerkar (2001), Beyond Local Search: Boundary-Spanning, Exploration, and Impact in the Optical Disc Industry, Strategic Management Journal 22 (4), 287 306.

Siegel, D.S., D.A. Waldman, L.E. Atwater and A.N. Link (2004), Toward a Model of the Effective Transfer of Scientific Knowledge from Academicians to Practitioners: Qualitative Evidence from the Commercialization of University Technologies, Journal of Engineering and Technology Management 21 (1-2), 115-142.

Slater, S.F. and J.C. Narver (1999), Market-Oriented Is More Than Being Customer-Led, Strategic Management Journal 20 (12), 1165-1168.

Spencer, J.W., T.P. Murtha and S.A. Lenway (2005), How Governments Matter to New Industry Creation, Academy of Management Review 30 (2), 321-337.

Subramaniam, M. and M.A. Youndt (2005), The Influence of Intellectual Capital on the Types of Innovative Capabilities, Academy of Management Journal 48 (3), 450-463.

Svejnar, J. (2002), Transition Economies: Performance and Challenges, Journal of Economic Perspectives 16 (1), 3-28.

Szulanski, G. (1996), Exploring Internal Stickiness: Impediments to the Transfer of Best Practice within the Firm, Strategic Management Journal 17, 27-43.

Teece, D.J. (1986), Transactions Cost Economics and the Multinational Enterprise: An Assessment, Journal of Economic Behavior \& Organization 7, 21-45.

Todorova, G. and B. Durisin (2007), Absorptive Capacity: Valuing a Reconceptualization, Academy of Management Review 32 (3), 774-786.

van den Bosch, F.A.J., H.W. Volberda and M. de Boer (1999), Coevolution of Firm Absorptive Capacity and Knowledge Environment: Organizational Forms and Combinative Capabilities, Organization Science 10 (5), 551-568. 
van Echtelt, F.E.A., F. Wynstra, A.J. van Weele and G. Duysters (2008), Managing Supplier Involvement in New Product Development: A Multiple-Case Study, Journal of Product Innovation Management 25, 180-201.

Vermunt, J.K. and J. Magidson (2005), Technical Guide for Latent Gold 4.0: Basic and Advanced, Belmont, Massachusetts.

von Hippel, E. (1988), The Sources of Innovation, New York.

Von Zedtwitz, M. and O. Gassmann (2002), Managing Customer Oriented Research, International Journal of Technology Management 24 (2/3), 165-193.

Wright, M., I. Filatotchev, R.E. Hoskisson and M.W. Peng (2005), Strategy Research in Emerging Economies: Challenging the Conventional Wisdom, Journal of Management Studies 26, 1-34.

Zahra, S.A. and G. George (2002), Absorptive Capacity: A Review, Reconceptualization, and Extension, Academy of Management Review 27 (2), 185-203. 


\section{Appendix}

Appendix A: Model goodness of fit for transition economies

\begin{tabular}{lcccccc}
\hline & LL & BIC(LL) & AIC(LL) & AIC3(LL) & No. of parameters & $\mathbf{R}^{2}$ \\
\hline 1-Class Regression & -669.42 & 1464.19 & 1372.83 & 1389.83 & 17 & 0.09 \\
2-Class Regression & -507.91 & 1325.52 & 1099.82 & 1141.82 & 42 & 0.70 \\
3-Class Regression & -450.80 & 1395.66 & 1035.60 & 1102.60 & 67 & 0.76 \\
4-Class Regression & -410.77 & 1499.95 & 1005.54 & 1097.54 & 92 & 0.87 \\
5-Class Regression & -367.26 & 1597.28 & 968.53 & 1085.53 & 117 & 0.88 \\
6-Class Regression & -353.47 & 1754.05 & 990.95 & 1132.95 & 142 & 0.89 \\
\hline
\end{tabular}

Appendix B: Model goodness of fit for market economies

\begin{tabular}{lcccccc}
\hline & LL & BIC(LL) & AIC(LL) & AIC3(LL) & No. of parameters & $\mathbf{R}^{2}$ \\
\hline 1-Class Regression & -1261.46 & 2658.59 & 2556.91 & 2573.91 & 17 & 0.05 \\
2-Class Regression & -1060.85 & 2456.90 & 2205.70 & 2247.70 & 42 & 0.49 \\
3-Class Regression & -1000.75 & 2536.23 & 2135.50 & 2202.50 & 67 & 0.57 \\
4-Class Regression & -969.51 & 2673.27 & 2123.01 & 2215.01 & 92 & 0.85 \\
\hline
\end{tabular}


Appendix C: Correlation matrix, variance inflation factors (VIF) and condition number for market economies

\begin{tabular}{|c|c|c|c|c|c|c|c|c|c|}
\hline & & (1) & (2) & (3) & (4) & (5) & (6) & (7) & (8) \\
\hline (1) & Source: Suppliers (std.) & 1.00 & & & & & & & \\
\hline (2) & Source: Customers (std.) & 0.10 & 1.00 & & & & & & \\
\hline (3) & Source: Competitors (std.) & 0.17 & 0.43 & 1.00 & & & & & \\
\hline (4) & Source: Universities (std.) & 0.10 & 0.20 & 0.19 & 1.00 & & & & \\
\hline (5) & Source: Research institutes (std.) & 0.11 & 0.16 & 0.16 & 0.55 & 1.00 & & & \\
\hline (6) & Source: Conferences (std.) & 0.19 & 0.21 & 0.27 & 0.34 & 0.27 & 1.00 & & \\
\hline (7) & Source: Fairs (std.) & 0.22 & 0.25 & 0.31 & 0.19 & 0.18 & 0.51 & 1.00 & \\
\hline (8) & R\&D exp. as share of sales (ratio) & -0.02 & 0.11 & 0.03 & 0.23 & 0.23 & 0.15 & 0.07 & 1.00 \\
\hline (9) & Continuous R\&D (d) & -0.02 & 0.22 & 0.11 & 0.33 & 0.24 & 0.23 & 0.12 & 0.31 \\
\hline (10) & Export as share of sales (ratio) & 0.03 & 0.11 & 0.03 & 0.12 & 0.09 & -0.01 & 0.09 & -0.01 \\
\hline (11) & Sales 1998 (logs) & 0.05 & 0.11 & 0.12 & 0.15 & 0.10 & 0.09 & 0.03 & -0.10 \\
\hline (12) & Part of group (d) & 0.03 & 0.08 & 0.07 & 0.14 & 0.16 & 0.04 & -0.01 & 0.04 \\
\hline (13) & Process innovation (d) & 0.15 & -0.03 & 0.02 & 0.04 & 0.05 & 0.09 & 0.07 & -0.03 \\
\hline (14) & Medium low-tech manuf. (d) & 0.01 & 0.02 & -0.05 & -0.04 & -0.01 & -0.05 & 0.01 & -0.09 \\
\hline (15) & Medium high-tech manuf. (d) & 0.02 & 0.08 & 0.06 & 0.06 & 0.03 & -0.02 & 0.02 & -0.04 \\
\hline (16) & High-tech manuf. (d) & -0.02 & 0.12 & 0.06 & 0.09 & 0.02 & 0.05 & 0.06 & 0.07 \\
\hline (17) & Low knowledge-int. services (d) & -0.01 & -0.05 & 0.00 & -0.08 & -0.10 & -0.03 & -0.06 & -0.07 \\
\hline (18) & Knowledge-int. services (d) & -0.08 & 0.04 & 0.05 & 0.18 & 0.13 & 0.18 & -0.07 & 0.33 \\
\hline (19) & Germany (d) & -0.09 & 0.19 & 0.21 & 0.16 & -0.03 & 0.19 & 0.10 & 0.01 \\
\hline (20) & Greece (d) & 0.03 & -0.09 & -0.10 & -0.07 & -0.07 & 0.00 & 0.00 & -0.09 \\
\hline (21) & Portugal (d) & 0.09 & -0.07 & -0.07 & -0.08 & -0.04 & -0.10 & 0.01 & -0.08 \\
\hline \multirow[t]{3}{*}{$(22)$} & Spain (d) & -0.02 & -0.07 & -0.07 & -0.08 & 0.11 & -0.09 & -0.06 & 0.08 \\
\hline & Variance Inflation Factor (VIF) & 1.15 & 1.34 & 1.36 & 1.70 & 1.58 & 1.64 & 1.55 & 1.31 \\
\hline & & (9) & (10) & (11) & (12) & (13) & (14) & (15) & (16) \\
\hline (9) & Continuous R\&D (d) & 1.00 & & & & & & & \\
\hline (10) & Export as share of sales (ratio) & 0.19 & 1.00 & & & & & & \\
\hline (11) & Sales 1998 (logs) & 0.19 & 0.25 & 1.00 & & & & & \\
\hline (12) & Part of group (d) & 0.07 & 0.03 & 0.18 & 1.00 & & & & \\
\hline (13) & Process innovaton (d) & 0.03 & 0.03 & 0.11 & 0.01 & 1.00 & & & \\
\hline (14) & Medium low-tech manuf. (d) & -0.06 & 0.01 & -0.03 & 0.00 & 0.01 & 1.00 & & \\
\hline (15) & Medium high-tech manuf. (d) & 0.14 & 0.19 & 0.07 & -0.03 & -0.03 & -0.23 & 1.00 & \\
\hline (16) & High-tech manuf. (d) & 0.16 & 0.05 & -0.02 & 0.01 & -0.06 & -0.12 & -0.12 & 1.00 \\
\hline (17) & Low knowledge-int. services (d) & -0.13 & -0.12 & 0.06 & 0.01 & 0.01 & -0.15 & -0.16 & -0.08 \\
\hline (18) & Knowledge-int. services (d) & 0.14 & -0.17 & -0.09 & 0.07 & -0.02 & -0.20 & -0.21 & -0.11 \\
\hline (19) & Germany (d) & 0.16 & -0.05 & 0.21 & 0.00 & 0.00 & 0.02 & 0.06 & 0.03 \\
\hline (20) & Greece (d) & -0.06 & -0.20 & -0.16 & -0.07 & 0.04 & 0.03 & -0.06 & -0.07 \\
\hline (21) & Portugal (d) & -0.13 & 0.12 & -0.05 & -0.07 & 0.11 & 0.03 & 0.00 & -0.05 \\
\hline \multirow[t]{3}{*}{ (22) } & Spain (d) & -0.04 & -0.01 & -0.06 & 0.11 & -0.09 & -0.03 & -0.07 & 0.06 \\
\hline & Variance Inflation Factor (VIF) & 1.39 & 1.30 & 1.28 & 1.09 & 1.07 & 1.33 & 1.42 & 1.22 \\
\hline & & (17) & (18) & (19) & (20) & $(21)$ & (22) & & \\
\hline (17) & Low knowledge-int. services (d) & 1.00 & & & & & & & \\
\hline (18) & Knowledge-int. services (d) & -0.14 & 1.00 & & & & & & \\
\hline (19) & Germany (d) & 0.05 & 0.12 & 1.00 & & & & & \\
\hline (20) & Greece (d) & 0.02 & -0.03 & -0.20 & 1.00 & & & & \\
\hline (21) & Portugal (d) & 0.03 & -0.11 & -0.22 & -0.11 & 1.00 & & & \\
\hline \multirow[t]{4}{*}{ (22) } & Spain (d) & -0.11 & -0.04 & -0.55 & -0.28 & -0.31 & 1.00 & & \\
\hline & Variance Inflation Factor (VIF) & 1.26 & 1.64 & 3.54 & 2.16 & 2.19 & 3.92 & & \\
\hline & Mean VIF & 1.66 & & & & & & & \\
\hline & Condition No. & 34.50 & & & & & & & \\
\hline
\end{tabular}


Appendix D: Correlation matrix, variance inflation factors (VIF) and condition number for transition economies

\begin{tabular}{|c|c|c|c|c|c|c|c|c|c|}
\hline & & $(1)$ & (2) & (3) & (4) & (5) & (6) & (7) & $(8)$ \\
\hline (1) & Source: Suppliers (std.) & 1.00 & & & & & & & \\
\hline (2) & Source: Customers (std.) & 0.31 & 1.00 & & & & & & \\
\hline (3) & Source: Competitors (std.) & 0.32 & 0.52 & 1.00 & & & & & \\
\hline (4) & Source: Universities (std.) & 0.26 & 0.18 & 0.29 & 1.00 & & & & \\
\hline (5) & Source: Research institutes (std.) & 0.24 & 0.15 & 0.29 & 0.66 & 1.00 & & & \\
\hline (6) & Source: Conferences (std.) & 0.29 & 0.25 & 0.35 & 0.43 & 0.36 & 1.00 & & \\
\hline (7) & Source: Fairs (std.) & 0.29 & 0.32 & 0.36 & 0.32 & 0.25 & 0.55 & 1.00 & \\
\hline (8) & R\&D exp. as share of sales (ratio) & 0.04 & 0.04 & -0.01 & 0.08 & 0.06 & 0.10 & 0.04 & 1.00 \\
\hline (9) & Continuous R\&D (d) & 0.11 & 0.21 & 0.13 & 0.16 & 0.06 & 0.22 & 0.18 & 0.26 \\
\hline (10) & Export as share of sales (ratio) & 0.01 & 0.07 & 0.02 & 0.04 & 0.01 & -0.02 & 0.08 & -0.07 \\
\hline (11) & Sales 1998 (logs) & 0.10 & 0.15 & 0.15 & 0.12 & 0.08 & 0.14 & 0.13 & -0.12 \\
\hline (12) & Part of group (d) & 0.00 & 0.07 & 0.04 & -0.02 & -0.04 & 0.00 & 0.01 & -0.05 \\
\hline (13) & Process innovation (d) & 0.10 & -0.01 & 0.05 & 0.09 & 0.10 & 0.08 & 0.03 & 0.00 \\
\hline (14) & Medium low-tech manuf. (d) & -0.03 & 0.03 & -0.04 & -0.01 & -0.02 & -0.05 & 0.02 & -0.07 \\
\hline (15) & Medium high-tech manuf. (d) & 0.00 & 0.08 & 0.06 & 0.08 & 0.02 & 0.01 & 0.07 & 0.00 \\
\hline (16) & High-tech manuf. (d) & 0.04 & 0.07 & 0.05 & 0.02 & -0.03 & 0.00 & 0.04 & 0.01 \\
\hline (17) & Low knowledge-int. services (d) & -0.05 & -0.09 & -0.04 & -0.11 & -0.05 & -0.07 & -0.08 & -0.09 \\
\hline (18) & Knowledge-int. services (d) & 0.02 & 0.00 & -0.02 & 0.07 & 0.04 & 0.12 & -0.06 & 0.37 \\
\hline (19) & Estonia (d) & 0.01 & -0.03 & -0.06 & -0.13 & -0.13 & -0.06 & -0.04 & -0.04 \\
\hline (20) & Hungary (d) & 0.14 & 0.20 & 0.22 & 0.11 & 0.15 & 0.16 & 0.16 & 0.01 \\
\hline (21) & Lithuania (d) & -0.04 & -0.20 & -0.04 & 0.17 & 0.25 & 0.04 & -0.01 & -0.05 \\
\hline \multirow[t]{3}{*}{$(22)$} & Slovak Rep. (d) & 0.04 & 0.06 & 0.03 & 0.05 & 0.00 & 0.08 & 0.09 & 0.11 \\
\hline & Variance Inflation Factor (VIF) & 1.24 & 1.54 & 1.60 & 2.01 & 1.94 & 1.76 & 1.61 & 1.26 \\
\hline & & (9) & $(10)$ & (11) & (12) & (13) & (14) & (15) & (16) \\
\hline (9) & Continuous R\&D (d) & 1.00 & & & & & & & \\
\hline (10) & Export as share of sales (ratio) & 0.10 & 1.00 & & & & & & \\
\hline (11) & Sales 1998 (logs) & 0.20 & 0.12 & 1.00 & & & & & \\
\hline (12) & Part of group (d) & -0.02 & 0.01 & 0.21 & 1.00 & & & & \\
\hline (13) & Process innovaton (d) & 0.02 & 0.03 & 0.07 & 0.01 & 1.00 & & & \\
\hline (14) & Medium low-tech manuf. (d) & 0.02 & 0.07 & 0.01 & 0.07 & 0.04 & 1.00 & & \\
\hline (15) & Medium high-tech manuf. (d) & 0.21 & 0.17 & 0.16 & 0.02 & -0.06 & -0.17 & 1.00 & \\
\hline (16) & High-tech manuf. (d) & 0.11 & 0.05 & 0.02 & -0.04 & 0.02 & -0.08 & -0.07 & 1.00 \\
\hline (17) & Low knowledge-int. services (d) & -0.17 & -0.20 & -0.01 & 0.02 & -0.05 & -0.20 & -0.20 & -0.09 \\
\hline (18) & Knowledge-int. services (d) & 0.15 & -0.23 & -0.15 & 0.01 & -0.02 & -0.18 & -0.17 & -0.08 \\
\hline (19) & Estonia (d) & 0.04 & -0.03 & -0.26 & -0.07 & -0.02 & 0.01 & -0.07 & -0.05 \\
\hline (20) & Hungary (d) & 0.11 & 0.03 & 0.12 & 0.00 & -0.01 & 0.03 & 0.08 & 0.08 \\
\hline (21) & Lithuania (d) & -0.29 & 0.13 & -0.20 & -0.12 & 0.11 & -0.06 & -0.10 & -0.10 \\
\hline \multirow[t]{3}{*}{ (22) } & Slovak Rep. (d) & 0.20 & 0.06 & 0.07 & -0.01 & -0.02 & 0.04 & 0.08 & 0.05 \\
\hline & Variance Inflation Factor (VIF) & 1.44 & 1.21 & 1.38 & 1.08 & 1.05 & 1.29 & 1.37 & 1.12 \\
\hline & & (17) & (18) & (19) & (20) & (21) & (22) & & \\
\hline (17) & Low knowledge-int. services (d) & 1.00 & & & & & & & \\
\hline (18) & Knowledge-int. services (d) & -0.21 & 1.00 & & & & & & \\
\hline (19) & Estonia (d) & 0.06 & -0.07 & 1.00 & & & & & \\
\hline (20) & Hungary (d) & -0.09 & -0.02 & -0.10 & 1.00 & & & & \\
\hline (21) & Lithuania (d) & 0.01 & -0.05 & -0.20 & -0.18 & 1.00 & & & \\
\hline \multirow[t]{4}{*}{$(22)$} & Slovak Rep. (d) & -0.08 & -0.02 & -0.07 & -0.06 & -0.12 & 1.00 & & \\
\hline & Variance Inflation Factor (VIF) & 1.37 & 1.64 & 1.25 & 1.17 & 1.56 & 1.10 & & \\
\hline & Mean VIF & 1.41 & & & & & & & \\
\hline & Condition No. & 31.57 & & & & & & & \\
\hline
\end{tabular}


Appendix E: Industry breakdown

\begin{tabular}{lll}
\hline Industry & NACE Code & Industry Group \\
\hline Manufacturing & & \\
Food and tobacco & $15-16$ & Low-technology \\
Textiles and leather & $17-19$ & Low-technology \\
Wood / paper / publishing & $20-22$ & Low-technology \\
Chemicals (incl. pharmaceuticals) & 24 & Medium high-technology \\
Plastics / rubber & 25 & Medium low-technology \\
Glass / ceramics & 26 & Medium low-technology \\
Metals & $27-28$ & Medium low-technology \\
Machinery and equipment & 29 & Medium high-technology \\
Office and computing machinery & 30 & High-technology \\
Electrical machinery and apparatus & 31 & Medium high-technology \\
Radio, TV and communication equipment & 32 & High-technology \\
Medical, precision and optical equipment & 33 & High-technology \\
Motor vehicles and trailers & 34 & Medium high-technology \\
Transport equipment & 35 & Medium high-technology \\
Manufacturing n.e.c. (e.g. furniture, & $36-37$ & Low-technology \\
jewelry, sports equipment and toys) & & \\
Services & & \\
Transport and storage (land, water, air) & $60-63$ & Low knowledge intensive \\
Post and Telecommunications & 64 & Knowledge intensive \\
Financial intermediation & $65-67$ & Knowledge intensive \\
Real estate, renting and business activities & $70-74$ & Knowledge intensive \\
\hline
\end{tabular}




\section{Appendix F: Descriptive statistics for dependent and independent variables}

\begin{tabular}{|c|c|c|c|c|c|}
\hline \multirow[t]{2}{*}{ Variable } & \multicolumn{2}{|c|}{ Market economies } & \multicolumn{2}{|c|}{ Transition economies } & \multirow{2}{*}{$\begin{array}{c}\text { Test of mean } \\
\text { differences }\end{array}$} \\
\hline & Mean & Std. Dev. & Mean & Std. Dev. & \\
\hline Share of sales with market novelties (ratio) & 0.11 & 0.19 & 0.12 & 0.20 & $*$ \\
\hline R\&D exp. as share of sales (ratio) & 0.02 & 0.09 & 0.02 & 0.06 & $* * *$ \\
\hline Continuous R\&D (d) & 0.34 & 0.47 & 0.29 & 0.46 & $* * *$ \\
\hline Export as share of sales (ratio) & 0.16 & 0.25 & 0.25 & 0.29 & $* * *$ \\
\hline Sales 1998 (logs) & 15.17 & 1.63 & 14.57 & 1.77 & $* * *$ \\
\hline Part of group (d) & 0.06 & 0.24 & 0.04 & 0.20 & $* * *$ \\
\hline Process innovation (d) & 0.62 & 0.49 & 0.61 & 0.49 & \\
\hline Low-tech manuf. (d) & 0.32 & 0.47 & 0.33 & 0.47 & \\
\hline Medium low-tech manuf. (d) & 0.18 & 0.39 & 0.15 & 0.36 & $* *$ \\
\hline Medium high-tech manuf. (d) & 0.19 & 0.39 & 0.14 & 0.35 & $* * *$ \\
\hline High-tech manuf. (d) & 0.06 & 0.23 & 0.03 & 0.18 & $* * *$ \\
\hline Low knowledge-int. services (d) & 0.10 & 0.29 & 0.19 & 0.39 & $* * *$ \\
\hline Knowledge-int. services (d) & 0.16 & 0.36 & 0.15 & 0.36 & \\
\hline Czech Rep. (d) & 0.00 & 0.00 & 0.52 & 0.50 & \\
\hline Estonia (d) & 0.00 & 0.00 & 0.10 & 0.29 & \\
\hline Hungary (d) & 0.00 & 0.00 & 0.08 & 0.27 & \\
\hline Lithuania (d) & 0.00 & 0.00 & 0.27 & 0.44 & \\
\hline Slovak Rep. (d) & 0.00 & 0.00 & 0.04 & 0.19 & \\
\hline Belgium (d) & 0.08 & 0.27 & 0.00 & 0.00 & \\
\hline Germany (d) & 0.28 & 0.45 & 0.00 & 0.00 & \\
\hline Greece (d) & 0.09 & 0.29 & 0.00 & 0.00 & \\
\hline Portugal (d) & 0.11 & 0.31 & 0.00 & 0.00 & \\
\hline Spain (d) & 0.44 & 0.50 & 0.00 & 0.00 & \\
\hline No. of obs. & & & & & \\
\hline
\end{tabular}

